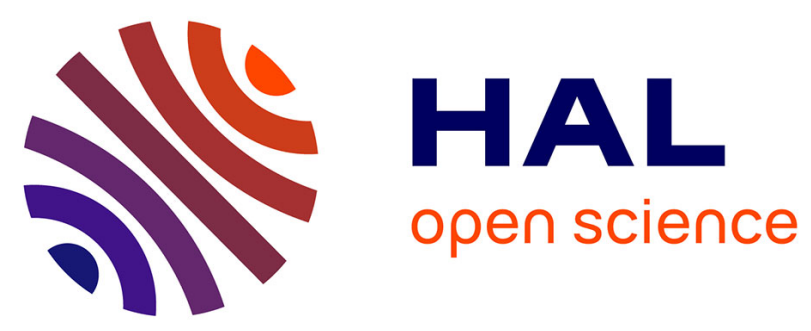

\title{
An Investigation of the Plasma Composition in Plasma-enhanced Hot Filament Catalytic Chemical Vapor Deposition of Carbon Nanotubes
}

Michal Guláš, Costel Sorin Cojocaru, Francois Le Normand, Samir Farhat

\section{- To cite this version:}

Michal Guláš, Costel Sorin Cojocaru, Francois Le Normand, Samir Farhat. An Investigation of the Plasma Composition in Plasma-enhanced Hot Filament Catalytic Chemical Vapor Deposition of Carbon Nanotubes. Plasma Chemistry and Plasma Processing, 2008, 28 (1), pp.123-146. 10.1007/s11090007-9111 . hal-00796265

\section{HAL Id: hal-00796265 https://hal.science/hal-00796265}

Submitted on 2 Mar 2013

HAL is a multi-disciplinary open access archive for the deposit and dissemination of scientific research documents, whether they are published or not. The documents may come from teaching and research institutions in France or abroad, or from public or private research centers.
L'archive ouverte pluridisciplinaire HAL, est destinée au dépôt et à la diffusion de documents scientifiques de niveau recherche, publiés ou non, émanant des établissements d'enseignement et de recherche français ou étrangers, des laboratoires publics ou privés. 


\title{
Plasma Chem Plasma Process
}

28 (2008):123-146

DOI 10.1007/s11090-007-9111-1

\section{An Investigation of the Plasma Composition in Plasma- enhanced Hot Filament Catalytic Chemical Vapor Deposition of Carbon Nanotubes}

\author{
M. Gulás C. S. Cojocaru* F. Le Normand* S. Farhat** \\ *Groupe Surfaces and Interfaces, IPCMS, UMR 7504 CNRS, 23, rue du Loess, Strasbourg, Cedex \\ 67034, France \\ **LIMHP, Université Paris 13, Av. J.B. Clément, Villetaneuse 93430, France
}

\begin{abstract}
A mixture of acetylene, hydrogen and ammonia $\left(\mathrm{C}_{2} \mathrm{H}_{2} / \mathrm{H}_{2} / \mathrm{NH}_{3}\right)$ is used to produce carbon nanotubes (CNTs) by a plasma-enhanced catalytic chemical vapor deposition process either without (PE CCVD) or with hot filaments-assistance (PE HF CCVD). A mathematical model based on Chemkin computer package is used for analyzing specific conditions of nanotube synthesis. Simulations are compared with optical emission spectroscopy (OES) measurements. Morphological and structural investigations on the grown carbon nanostructures are also performed using scanning electron microscopy (SEM) and transmission electron microscopy (TEM). It was shown that the significant change in the density and the morphology of the CNTs grown in the presence of $\mathrm{NH}_{3}$ could be mainly explained by the gas phase formation of $\mathrm{CN}$ and $\mathrm{HCN}$. Both species display a high etching activity, whereas the species $\mathrm{C}, \mathrm{CH}, \mathrm{CH}_{2}, \mathrm{CH}_{2}(\mathrm{~S}), \mathrm{C}_{2}$ and $\mathrm{C}_{2} \mathrm{H}$ are expected to be the most probable carbon nanotube precursors.
\end{abstract}

Keywords Plasma composition Carbon nanotubes Plasma enhanced CVD Chemical kinetics

\section{Introduction}

Carbon nanotube (CNT) synthesis began in the early 1990s and is now in wide expansion because of many potential industrial applications. This is especially due to a singular combination of chemical and physical properties coupled with the relatively new ability to 
grow them well-aligned and perpendicular to a flat substrate. Three main methods of CNTs synthesis exist in the literature, they are namely the arc discharge, the laser ablation and the catalytic chemical vapor deposition (CCVD) methods. Whatever is the method used, it implies for carbon deposition the interaction between gaseous species, either vaporized by a physical process or chemically activated, and a substrate. The precise role of the different molecules, atoms, ions, neutral and excited radicals, is still not very clear in the CNT growth but this did not prevent growth scenarios to be proposed in the literature. In the laser ablation [1] and in the electric arc [2] methods, gas temperature is supposed to be above the graphite sublimation temperature, i.e. $* 4,000 \mathrm{~K}$. Only carbon and noble gas elements are present in the system. To explain nanotube growth at such high temperatures, three growth mechanisms were proposed. In the first scenario, the growth occurs in the gas phase by carbon and catalyst cluster aggregation. In the second scenario, also called "scooter" mechanism, the growth is caused by heterogeneous adsorption of small carbon clusters $C_{1}, C_{2}$ and $C_{3}$ on open-ended nanotubes. Finally in the third scenario, the growth occurs via dissolution of carbon into a molten metal catalyst followed by diffusion of dissolved carbon to the particle surface, and precipitation of this carbon taking the shape of nanotubes.

By contrast, in the CCVD method, gas temperature is relatively low, and due to the presence in the feed gas of hydrogen, nitrogen and some other elements like oxygen, the chemical system is by far richer and therefore much more complex. Nevertheless, since this method permits to achieve high yield of high purity CNTs with low cost and easy scaling up, it is much more promising, especially for direct synthesis of microelectronic devices [1, 3]. In addition, the activation of the gas by different sources of energy like plasma and/or hot filaments permits various process improvements such as a better CNTs growth rate, a better mutual orientation as well as a higher carbon selectivity [4].

In these PE (HF) CCVD methods, controlling the feed gas decomposition provides an efficient tool to better improve the activation of the catalytic nanoparticles as well as to enhance the selective carbon etching and then to promote CNT formation and even orientation. In addition, the surface activation by a catalytic particle lowers the growth temperature to about $900-1,300 \mathrm{~K}$, with the catalytic particles being held either on the top or on the base of the CNTs, respectively.

Carbon nanotubes growth in the PE (HF) CCVD process is obtained through decomposition of hydrocarbon like $\mathrm{C}_{2} \mathrm{H}_{2}, \mathrm{CH}_{4}$ or carbon monoxide $\mathrm{CO}$ gas molecules [1, 3, 4]. Therefore there is a clear distinction between the thermal CCVD process, where no decomposition in gas phase occurs, and the PE (HF) CCVD process where preliminary decomposition in gas phase occurs. Moreover in both cases the incoming or activated gas is subsequently activated on the catalytic particle followed by carbon diffusion throughout or over the particle and finally by carbon condensation [5, 6]. Moreover, recent results have pointed out that the dissociation step of the carbon-based species on the catalytic particle is the rate limiting step [7-9]. From these observations many carbon-based species are expected to participate as precursors of CNTs growth.

Some few experimental investigations were carried out in the literature in order to measure some species in the plasma. Numerical models can complement these measurements by providing additional information that give a guideline for building a mechanistic understanding of the CNTs growth and help to optimize the PE HF CCVD process. Unfortunately PE HF CCVD models are not highly developed in the literature because the coupling of non-equilibrium plasma with nonlinear chemical system renders modeling difficult. By contrast however, detailed models were developed in the past for diamond [10-14] with similar HF CVD and PE (microwave) CVD processes or for nanotube growth 
with a thermal plasma electric arc discharge process [15]. Attempts to simulate gas composition in the non-thermal cold plasma environment were performed by Hash et al. $[16,17]$. They studied the composition of cold plasma in either Direct Current-activated CCVD (DC CCVD process with $\mathrm{Ar} / \mathrm{C}_{2} \mathrm{H}_{2} / \mathrm{NH}_{3}$ atmosphere), or in the presence of hot filaments (DC HF CCVD process with $\mathrm{C}_{2} \mathrm{H}_{2} / \mathrm{NH}_{3}$ atmosphere). From these studies it was concluded that the hot filament was not decisive for CNTs growth. Nevertheless, these conclusions are in some disagreement with experimental results $[18,19]$ where the crucial role of hot filaments is underlined.

To alleviate this contradiction, an investigation of the plasma chemistry during carbon nanotubes production is presented in this study. Our results include Optical Emission Spectroscopy (OES) measurements as well as numerical results. A particular attention will be given to the analysis of the effect of the source of activation (PE CCVD or PE HF CCVD modes), as well as the effect of ammonia and acetylene concentrations on the $\mathrm{C}_{2} \mathrm{H}_{2}$ / $\mathrm{H}_{2} / \mathrm{NH}_{3}$ gas phase chemistry.

\section{Experimental}

\section{Apparatus}

The synthesis of carbon nanotubes was performed in an Ultra High Vacuum (UHV) CVD set-up provided with two chambers. The first chamber served for deposition of catalytic cobalt and for surface analyses, while the second chamber was used for CNTs growth. The CVD growth chamber allowed working either in a PE CCVD mode or in a PE HF CCVD mode. A scheme and a photo of the experimental set-up are shown in Fig. 1a and b, respectively. The negative glow discharge above the sample can be evidenced. The catalyst preparation and the experimental procedure were already described in details in previous works $[19,20]$. The incoming gas of molar composition of $\mathrm{H}_{2} / \mathrm{C}_{2} \mathrm{H}_{2}(80 / 20)$ with an overall flow rate $100 \mathrm{sccm}$ was activated by either hot filaments or by a DC electric glow discharge. In some experiments, small amounts of $\mathrm{NH}_{3}$ (1-3\% of the gas composition) were added to the main gas mixture. The pressure during synthesis was maintained at 10 mbar.
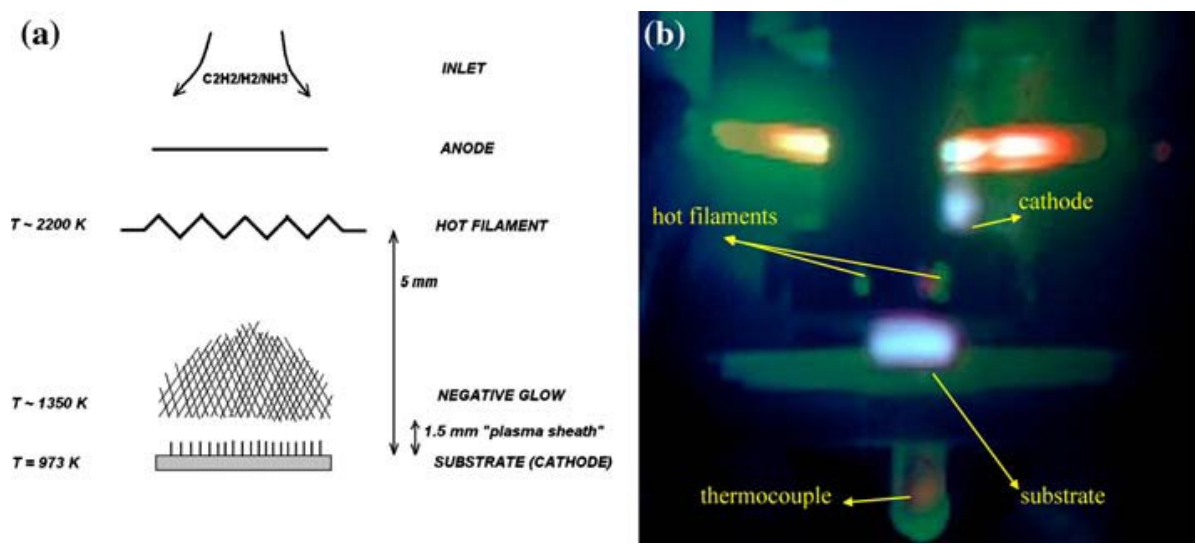

Fig. 1 CCVD chamber for CNTs synthesis: (a) (left): Scheme of the PE HF CCVD reactor; (b) (right): Optically-filtered image of the reactor (temperature of filaments $* 1,473 \mathrm{~K}$, power of plasma $* 1 \mathrm{~W}$ 
Two tungsten filaments of $5 \mathrm{~mm}$ length were placed at $5 \mathrm{~mm}$ above the substrate and a power of $P_{f}=150 \mathrm{~W}$ was used to heat them to a temperature of $T_{f} * 2,200 \mathrm{~K}$. For the direct current glow discharge, an extraction power $\mathrm{P}_{\mathrm{p}} * 1 \mathrm{~W}$ (around $300 \mathrm{~V}$ times $3 \mathrm{~mA}$ ) was used [20]. In addition, an infrared lamp, settled below the substrate, heated the sample to keep the substrate temperature at $973 \mathrm{~K}$, regardless the gas activation mode.

\section{Optical Emission Spectroscopy}

An optical fiber probe ended by a rectangular slit (1 mm height; $2 \mathrm{~mm}$ width) was settled at a position $1 \mathrm{~mm}$ over the substrate in the glow discharge zone. The fiber transferred the collected light from the plasma to a photomultiplier through a Jobin-Yvon HR 320 monochromator using a 1,200 lines/mm grating. With this set-up, we were able to monitor the 400-700 nm wavelength region with a spectral resolution of $2 \mathrm{~nm}$ [21] and a good coverage of many neutral lines as well as the Swan bands $(\mathrm{Dv}=0$ and $\mathrm{Dv}=1)$. The wavelength calibration was performed using the Balmer series of atomic hydrogen emission lines $\mathrm{H}_{\mathrm{a}}, \mathrm{H}_{\mathrm{b}}, \mathrm{H}_{\mathrm{c}}$ and $\mathrm{H}_{\mathrm{d}}$ lines at 656.3, 486.1, 434.0 and $410.2 \mathrm{~nm}$, respectively [22, 23]. Once the hot filaments between the cathode and the substrate were activated, a noncoherent radiative emission was induced, increasing markedly the background. To remove it, the spectrum with the heated filaments $(150 \mathrm{~W}, 2,170 \mathrm{~K})$ but without plasma was first recorded as a reference spectrum. Then, the spectrum in the HF DC CCVD mode was recorded and subtracted from this reference after normalization at $400 \mathrm{~nm}$. A typical spectrum obtained after this background subtraction is given in Fig. 2. Most of the lines could be easily assigned, and the major optical emission lines arose from atomic and molecular species like $\mathrm{H}, \mathrm{CH}, \mathrm{H}_{2}, \mathrm{CN}, \mathrm{NH}, \mathrm{N}_{2}$ and $\mathrm{C}_{2}$, respectively.

\section{Scanning Electron Microscopy (SEM) and Transmission Electron Microscopy (TEM)}

The morphology and the size of the nanotube samples were studied by SEM and TEM. SEM observations were achieved with a XL30S-FEG PHILIPPS apparatus operating at $3 \mathrm{kV}$. HRTEM observations were performed with a TOPCON 002B microscope operating

Fig. 2 Typical OES spectrum obtained from DC glow discharge with a mixture of $\mathrm{C}_{2} \mathrm{H}_{2} / \mathrm{H}_{2} / \mathrm{NH}_{3}(20 / 79 / 1)$ at $\mathrm{D}=100 \mathrm{sccm}, \mathrm{T}_{\mathrm{f}}=2,200 \mathrm{~K}$ and $\mathrm{T}_{\mathrm{g}}=1,350 \mathrm{~K}[24]$

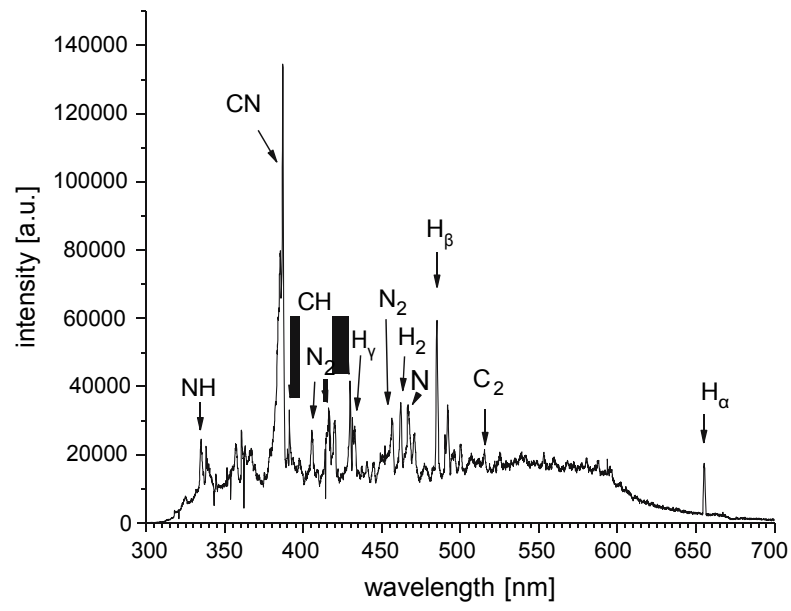


at $200 \mathrm{kV}$. To evaluate the growth rates, samples were also observed with a special substrate holder allowing observations with $45^{\circ}$ incidence angle but within a limited focalization area of the electron beam.

\section{Modeling}

\section{Overview of the Model}

Simulations of the acetylene/hydrogen/ammonia system were performed in specific CCVD conditions using the CHEMKIN ${ }^{\mathrm{TM}}$ database and software package [25]. In zero spatial dimension (OD), we used the AURORA software to estimate the plasma composition at equilibrium, given gas and electron temperatures. In one spatial dimension (1D), the SPIN code was used to calculate the distribution of steady-state species, given a gas temperature profile. Since, in CCVD process, carbon was supplied by a gaseous hydrocarbon mixed with hydrogen and ammonia, gas phase chemistry must include species in the $\mathrm{C} / \mathrm{H} / \mathrm{N}$ system with their reaction schemes and thermodynamic properties. In the case of the carbon nanotube formation by a PE HF CCVD process, the incoming gas was activated by hot filaments and the simulation domain lied between the filament and the plasma, hence the SPIN program was used to simulate this reactor region in (1D) spatial dimension. The gas temperature profile $\mathrm{T}_{\mathrm{g}}(\mathrm{d})$ between the filaments and the substrate was taken from Mankelevich et al. [12, 26]. They studied similar $\mathrm{CH}_{4} / \mathrm{H}_{2}$ and $\mathrm{C}_{2} \mathrm{H}_{2} / \mathrm{H}_{2}$ mixtures with similar gas phase conditions for diamond growth. According to these authors, the temperature profile was given by:

$$
\mathrm{T}_{\mathrm{g}} \text { ठdp } 1 / 4 \mathrm{~T}_{0} \times \mathbf{f} 1-1 / 21-\mathrm{T}_{\mathrm{L}} / \mathrm{T}_{0} \mathrm{p} 2 \times \ln ð \mathrm{~d} / \mathrm{R}_{\mathrm{f}} \mathrm{p}=\ln \circlearrowright \mathrm{L} / \mathrm{R}_{\mathrm{f}} \mathrm{pg}=2
$$

where $T_{0}, T_{L}$ and $T_{g}(d)$ were the gas temperatures, very close to the filaments (d C 0 ), at the distance $\mathrm{L}$ from the filament and at the distance $\mathrm{d}(0 \backslash \mathrm{d} \backslash \mathrm{L})$, respectively, and $\mathrm{R}_{\mathrm{f}}=150 \mathrm{Im}$ was the filament radius. Many results indicated that $\mathrm{T}_{0}$ could be approximated to $T_{0} \& T_{f}-500$ where $T_{f}$ was the true filaments temperature. $T_{L}$ corresponded to the temperature $(975 \mathrm{~K})$ at $\mathrm{L}=5 \mathrm{~mm}$ from the filaments $\left(\mathrm{T}_{\mathrm{L}}=\mathrm{T}_{\mathrm{S}}\right.$ temperature of the substrate). Details of the processes occurring at the filament surface, especially the widely studied $\mathrm{H}_{2}$ dissociation $[27,28]$, have not been studied here. Thus, we adopted for all our simulations the following temperature profile:

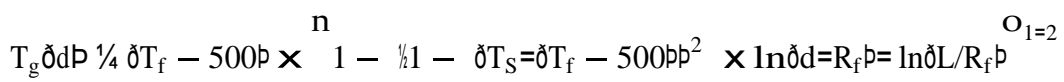

The simulations using SPIN were not included in the case of PE CCVD, where the incoming gas is activated only by an electric discharge.

The composition of the plasma at equilibrium was modeled using the AURORA software by assuming the direct current DC electric glow discharge as a well mixed (OD) reactor with a net generation of chemical species within the plasma volume and without loss of species to the substrate and to the reactor surfaces. The model assumed two temperatures, translational/rotational $\mathrm{T}_{\mathrm{g}}$ and electronic $\mathrm{T}_{\mathrm{e}}$ temperatures, each describing a Maxwell/Boltzmann distribution for its respective mode. The structure of direct current glow discharge was well known [29, 30], since the highest concentration of ions lied in the plasma region of negative glow discharge. In the positive column, the concentration of electrons and ions was about two to three orders of magnitude lower around $10^{9}-10^{10} \mathrm{~cm}^{-3}$ 
[30]. Because of the smaller number density of ions and electrons in the positive column, it was possible to neglect the influence of charged species in this positive column. So it was not necessary to simulate the complete evolution of DC glow since the major influence on gas phase chemistry occurred in the region from negative glow to cathode (plasma sheath). These properties of glow discharge led, in a first approach, to simplify the model by simulating the concentrations of species only in the region of the negative glow. The thickness of plasma sheath was experimentally estimated to around $1.5 \mathrm{~mm}$ from direct visualization (Fig. 1). This observation was further checked using the theoretical ChildLangmuir theory within the assumption of low pressure plasma [31, 32] where the thickness of plasma sheath d was calculated from the equation:

$$
\mathrm{d} 1 / 4 \quad \mathrm{n} 4 \times \mathrm{e}_{0} \times \partial 2 \mathrm{e}^{1=2} \times \mathrm{V}_{0}^{3=2}=9 \times \mathrm{m}_{\mathrm{i}} \times \mathbf{j}_{\mathrm{i}}^{\mathbf{O}_{1=2}}
$$

Where $\mathrm{e}_{0}$ was the electrical permittivity in vacuum, e was the electron charge, $\mathrm{V}_{0}$ was the potential drop, $m_{i}$ and $j_{i}$ were the ion mass and the ion current, respectively. It was further assumed that the plasma sheath was much larger than the mean free path (mfp) $k_{i}$ of the ionic species $\mathrm{M}_{\mathrm{i}}$. This $\mathrm{mfp}$ could be estimated from the Child's law limited by collisional diffusion according to:

$$
\mathrm{k}_{\mathrm{i}} 1 / 4 \mathrm{p} \times \mathrm{M}_{\mathrm{i}} \times \mathrm{d}_{5} \times \mathrm{j}_{0}^{2}=4: 115 \times \mathrm{e} \times \mathrm{V}_{0}^{3} \times \mathrm{e}^{2}
$$

Where $\mathrm{j}_{0}$ and $\mathrm{V}_{0}$ were the current density $\left(* 6 \mathrm{~mA} / \mathrm{cm}^{2}\right)$ and the potential drop $(-310 \mathrm{~V})$, respectively. For molecular hydrogen $\mathrm{H}_{2}$, the mfp extracted from expression 4 could be estimated to $10 \mathbf{1 m}$, which was in good agreement with reported data under similar conditions [33].

\section{Aurora Model Equations}

We used AURORA software to simulate the average steady-state bulk plasma properties, like electron density and degree of dissociation, given gas and electron temperatures. Even though the steady-state solution is searched for, the mass conservation of each gas-phase species was written as a time-dependent equation:

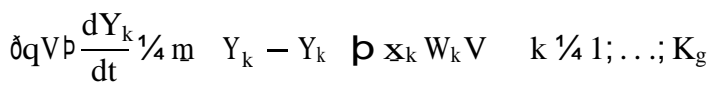

where $\mathrm{q}$ was the mass density, $\mathrm{V}$ was the reactor volume, $\mathrm{m}$ was the inlet mass flow rate, $Y_{k}{ }^{*}$ and $Y_{k}$ were the inlet and outlet mass fractions of the kth species, respectively, $x_{k}$ was the net molar rate of production of the kth species by gas-phase chemical reaction per unit volume, $\mathrm{W}_{\mathrm{k}}$ was the molecular weight of the kth species and $\mathrm{K}_{\mathrm{g}}$ was the total number of gas-phase species given below.

\section{Spin Model Equations}

We used SPIN software to determine species and velocity profiles in a steady-state 1D HF CCVD region. This model was a boundary values problem consisting of a set of ordinary differential equations, solved by a finite difference procedure and incorporating stagnationpoint flow and temperature-dependent fluid properties. SPIN model equations included 
continuity relation (6), radial momentum conservation (7) and species conservation (8) relations in $1 \mathrm{D}$ HF CCVD region.

Continuity Relation

$$
\frac{1}{\mathrm{q}} \frac{\mathrm{oq}}{\mathrm{ot}} 1 / 4-\frac{\mathrm{ou}}{\mathrm{ox}}-2 \mathrm{~V}-\frac{\mathrm{u}}{\mathrm{q}} \frac{\mathrm{oq}}{\mathrm{ox}} 1 / 40
$$

Radial Momentum Conservation

$$
\mathrm{q} \frac{\mathrm{oV}}{\mathrm{ot}} 1 / 4-\frac{\mathrm{o}}{\mathrm{ox}} \mathrm{\partial l} \frac{\mathrm{oV}}{\mathrm{ox}} \mathrm{p}-\mathrm{qu} \frac{\mathrm{oV}}{\mathrm{ox}}-\mathrm{q} \mathrm{V}^{2}-\frac{1}{\mathrm{r}} \frac{\mathrm{op}}{\mathrm{or}} 1 / 40
$$

Species Continuity Conservation

$$
q \frac{o Y_{i}}{o t} p \frac{o ð q Y_{i} V_{i} p}{o x} p q u \frac{o Y_{i}}{o x} 1 / 4 M_{i} x_{i} \quad ð_{i} 1 / 41 ; \ldots ; K_{g} p
$$

Although these equations were stated in their transient form, the solution was obtained when all time derivatives were zero. The independent variables were the distance normal to the substrate $\mathrm{x}$, and the time $\mathrm{t}$. The dependent variables were axial $\mathrm{u}$ and radial $\mathrm{V}$ velocities, the mass density $q$ and the gas-phase species mass fractions $Y_{i}$. In the radial momentum Eq. 7, p was the spatially varying component of the pressure. The molecular weight of species $i$ was $M_{i}$ and the net chemical production rate of species $i$ by gas-phase reaction was $x_{i}$ in Eq. 8. The species diffusion velocity $V_{i}$ was calculated from mixture diffusion coefficient and species gradient.

\section{Reaction Schemes and Thermodynamic Properties}

Two chemical systems were considered in our simulations. The first system concerned the mixture $\mathrm{C}_{2} \mathrm{H}_{2} / \mathrm{H}_{2}$ with more than 140 reactions involving 31 species distributed as 15 neutral species involving $\mathrm{H}, \mathrm{H}_{2}, \mathrm{C}, \mathrm{CH}, \mathrm{CH}_{2}, \mathrm{CH}_{2}$ (Singlet), $\mathrm{CH}_{3}, \mathrm{CH}_{4}, \mathrm{C}_{2}, \mathrm{C}_{2} \mathrm{H}, \mathrm{C}_{2} \mathrm{H}_{2}$, $\mathrm{C}_{2} \mathrm{H}_{3}, \mathrm{C}_{2} \mathrm{H}_{4}, \mathrm{C}_{2} \mathrm{H}_{5}, \mathrm{C}_{2} \mathrm{H}_{6}$ and 16 charged species involving $\mathrm{e}^{-}, \mathrm{H}^{-}, \mathrm{H}^{+}, \mathrm{H}_{2},{ }^{+} \mathrm{C},{ }^{+} \mathrm{CH}, \mathrm{CH}_{2}^{+}$, $\mathrm{CH}_{3}^{+}, \mathrm{CH}_{4}^{+}, \mathrm{C}_{2}^{+}, \mathrm{C}_{2} \mathrm{H}^{+}, \mathrm{C}_{2} \mathrm{H}_{2}^{+}, \mathrm{C}_{2} \mathrm{H}_{3}^{+}, \mathrm{C}_{2} \mathrm{H}_{4}^{+}, \mathrm{C}_{2} \mathrm{H}_{5}^{+}, \mathrm{C}_{2} \mathrm{H}_{6}^{+}$. The second system included the nitrogen element for the mixture $\mathrm{C}_{2} \mathrm{H}_{2} / \mathrm{H}_{2} / \mathrm{NH}_{3}$ with more than 200 reactions involving 45 species distributed as 29 neutral species involving the species given above with in addition $\mathrm{N}, \mathrm{NH}, \mathrm{NH}_{2}, \mathrm{NH}_{3}, \mathrm{~N}_{2}, \mathrm{NNH}, \mathrm{N}_{2} \mathrm{H}_{2}, \mathrm{~N}_{2} \mathrm{H}_{3}, \mathrm{~N}_{2} \mathrm{H}_{4}, \mathrm{CN}, \mathrm{HCN}, \mathrm{H}_{2} \mathrm{CN}, \mathrm{NCN}, \mathrm{C}_{2} \mathrm{~N}_{2}$ and the 16 charged species.

The thermochemical properties for all species were taken mainly from CHEMKIN ${ }^{\mathrm{TM}}$ thermodynamic database as well as other databases [25, 34-39]. Rates of reaction $\mathrm{k}$ were given in Arrhenius form according to Eq. 9.

$$
\mathrm{k} 1 / 4 \mathrm{AT}^{\mathrm{b}} \exp ^{\partial_{\mathrm{RT}}^{\mathrm{E} P}}
$$

where $\mathrm{A}, \mathrm{b}$ and $\mathrm{E}$ were the pre-exponential factor, the temperature exponent and the activation energy, respectively. They are displayed in Appendix A-C. 


\section{Initial and Boundary Conditions}

For PE HF CCVD simulations, first the HF CCVD region was simulated (SPIN) using the chemical reactions from Appendix A and Appendix A-B for the gas mixtures $\mathrm{C}_{2} \mathrm{H}_{2} / \mathrm{H}_{2}$ and $\mathrm{C}_{2} \mathrm{H}_{2} / \mathrm{H}_{2} / \mathrm{NH}_{3}$, respectively. Then the DC glow discharge was simulated (AURORA) using the reactions from Appendix A-C with dependence on the possible addition of $\mathrm{NH}_{3}$. For the PE CCVD reactor only the AURORA model was used. So again reactions from Appendix A-C were used.

Initial conditions were calculated using EQUILIBRIUM, another part of the CHEM$\mathrm{KIN}^{\mathrm{TM}}$ software. For the PE HF CCVD mode, the equilibrium was calculated at the gas temperature near the filaments and a pressure of $10 \mathrm{mbar}$ at a distance $5 \mathrm{~mm}$ from the substrate ( $3.5 \mathrm{~mm}$ from the plasma sheath). In PE CCVD simulations, equilibrium was calculated at the gas temperature of plasma (in negative glow 1,300-1,400 K, dependent on the gas composition) based on the OES measurements reported elsewhere [24].

Surface reactions were taken from the model presented by Grujicic et al. [40, 41] and then extended to employ more hydrocarbon species expected to participate to the CNTs growth. This model was based on the following reactions: (i) chemisorption of hydrogen and hydrocarbon molecules on a catalytic Co surface, (ii) hydrogen abstractions down to hydrocarbon decomposition and (iii) diffusion of carbon atoms followed by carbon nanotube formation. These surface reactions are presented in Appendix D. They consist in 33 reactions where $(\mathrm{S})$ stands for surface species, $(\mathrm{Co})$ and $(\mathrm{T})$ are free and occupied sites of the catalyst, and (NT) stands for carbon nanotube. As it can be seen, ions were not used in the set of surface reactions, although it was observed that ion bombardment can have positive and also negative impact on activation of the substrate and nucleation of CNTs $[42,43]$. It is assumed however that their contribution to the rate growth is low.

Since no other carbon phases were incorporated in this model, the density of growth sites $\mathrm{C}$ was calculated by geometrical considerations from Hamada's indices $\mathrm{n}$ and $\mathrm{m}$. We considered a triangular arrangement of carbon nanotubes within a bundle and divided the number of atoms per hexagon by the surface of the hexagon using the equation

$$
\text { C } 1 / 4 \underset{3}{3} \frac{3 N_{\mathrm{at}}}{3 \delta \mathrm{d}_{\mathrm{CNT}} \mathbf{p} \mathrm{d}_{\mathrm{NT}-\mathrm{NT}} p^{2}} \times \frac{1}{\mathrm{~N}_{\mathrm{Av}}}
$$

with $\mathrm{N}_{\mathrm{at}}$ the number of atoms per unit cell (nanotube), $\mathrm{d}_{\mathrm{CNT}}$ the nanotube diameter, $\mathrm{d}_{\mathrm{NT}}-\mathrm{NT}=0.340 \mathrm{~nm}$ the distance between two adjacent nanotubes and $\mathrm{N}_{\mathrm{Av}}$ the Avogadro's number. For example, for a $(10,10)$ nanotube, $\mathrm{d}_{\mathrm{CNT}}=1.357 \mathrm{~nm}$ and $\mathrm{N}_{\mathrm{at}}=20$, hence the site density was $\mathrm{C}=6.66910^{-10} \mathrm{moles} / \mathrm{cm}^{2}$ [15].

The surface site density is often assumed to be conserved. The surface-species conservation equation is given by

$$
\frac{\mathrm{dZ}_{\mathrm{CR}}}{\mathrm{dt}} 1 / 4 \frac{\mathrm{s} C R}{\mathrm{C}} 1 / 40
$$

where $\mathrm{Z}_{\mathrm{CR}}$ is surface species site fraction. The chemical production $\mathrm{s}_{\mathrm{CR}}$ of surface species by surface reactions is given by the sum over the rate-of-progress variables for all surface reactions of Appendix D. The rate of production $\mathrm{s}_{\mathrm{CR}}$ expressed in moles $/ \mathrm{cm}^{2} / \mathrm{min}$ is converted to linear nanotube growth rate $\mathrm{G}$ in $\mathbf{I m} / \mathrm{min}$ by using nanotube bulk mass density $\mathrm{q}_{\mathrm{CNT}}=2.20 \mathrm{~g} / \mathrm{cm}^{3}$ and molecular weight $\mathrm{M}_{\mathrm{CNT}}=12.01 \mathrm{~g} / \mathrm{mol}$ using the equation 


$$
\mathrm{G} 1 / 4 \frac{\mathrm{s}_{\mathrm{CR}} \mathrm{M}_{\mathrm{CNT}}}{\mathrm{q}_{\mathrm{CNT}}}
$$

Of course these calculations are rough approximations, as they assume that the growth rate is not dependent on the limited active surface area of the catalyst.

\section{Results and Discussion}

The model Eqs 5 and 6-8 are solved using the base values and range of physical parameters reported in Table 1 . In this table, the electron temperature is estimated from optical emission spectroscopy (OES) measurements while rotational temperature is evaluated from the emission spectra of the $(0-0) C_{2}\left(d^{3} P_{g}\right) ? C_{2}\left(a^{3} P_{u}\right)$ transition using numerical simulation of the spectra. The rotational temperature as a function of the $\mathrm{C}_{2} \mathrm{H}_{2}$ content in a $\mathrm{C}_{2} \mathrm{H}_{2} / \mathrm{H}_{2}$ mixture was reported elsewhere by our group [24]. The OES is also used to determine relative values of different species as in previous studies of CNTs grown by plasma-enhanced CVD [44-46].

The most abundant neutral species in PE HF CVD simulations with "base value" conditions are presented in Fig. 3 as a function of the position in between the hot filaments and the substrate. As it was mentioned above, hot filaments were placed $5 \mathrm{~mm}$ above the substrate and the negative glow from a direct current glow discharge plasma occurs at around $2 \mathrm{~mm}$ from the substrate. The plasma sheath region lays from $1.5 \mathrm{~mm}$ to substrate. It can be seen that, apart from $\mathrm{H}_{2}$ and $\mathrm{C}_{2} \mathrm{H}_{2}, \mathrm{H}, \mathrm{HCN}, \mathrm{N}_{2}, \mathrm{C}_{2} \mathrm{H}_{4}, \mathrm{C}_{2} \mathrm{H}_{3}, \mathrm{CH}_{4}, \mathrm{CH} 3, \mathrm{C}_{2} \mathrm{H}, \mathrm{C}$ and $\mathrm{CN}$ are the most abundant species with strong variations near the filaments and smooth evolution in the plasma sheath.

The species $\mathrm{C}, \mathrm{CH}, \mathrm{CH}_{2}, \mathrm{CH}_{3}, \mathrm{C}_{2}$ and $\mathrm{C}_{2} \mathrm{H}$ are supposed to be the most probable carbon nanotube precursors. Adsorption of these hydrocarbons on transition metals surface followed by hydrogen abstraction results in the catalytic growth of carbon nanotubes. A growth rate of $G=0.9 \mathrm{Im} / \mathrm{min}$, at base value conditions from Table 1 , is obtained from these gas phase and surface simulations. Such simulated growth rate is in very good agreement with experimentally observed growth rate around $11 \mathrm{~m} / \mathrm{min}$. It should be noted however that the simulated growth rate is assumed as linear.

Table 1 Parameters used in the simulations of PE CCVD and PE HF CCVD modes of carbon nanotubes synthesis

\begin{tabular}{lll}
\hline Parameter & Base value & Range \\
Gas temperature, $\mathrm{T}_{\mathrm{g}}$ & $1,350 \mathrm{~K}$ & $1,300-1,400 \mathrm{~K}$ \\
Electron temperature, $\mathrm{T}_{\mathrm{e}}$ & $1.5 \mathrm{eV}$ & - \\
Filament temperature, $\mathrm{T}_{\mathrm{f}}$ & $2,200 \mathrm{~K}$ & - \\
Substrate temperature, $\mathrm{T}_{\mathrm{s}}$ & $975 \mathrm{~K}$ & - \\
Feed $\mathrm{C}_{2} \mathrm{H}_{2}$ mol\% & $20 \%$ & $10-30 \%$ \\
Feed $\mathrm{NH}_{3}$ mol\% & $1 \%$ & $0-3 \%$ \\
Plasma volume, $\mathrm{V}_{\text {plasma }}$ & $1 \mathrm{~cm}^{3}$ & - \\
Pressure & $10 \mathrm{mbar}$ & - \\
Inlet flow rate & $100 \mathrm{sccm}$ & - \\
Plasma power, $\mathrm{P}_{\mathrm{p}}$ & $* 1 \mathrm{~W}$ & - \\
\hline
\end{tabular}


Fig. 3 Calculated concentration profiles for the most abundant molecules and radicals in the $\mathrm{PE}$ HF CCVD mode. The conditions are reported in Table 1 as "base value”

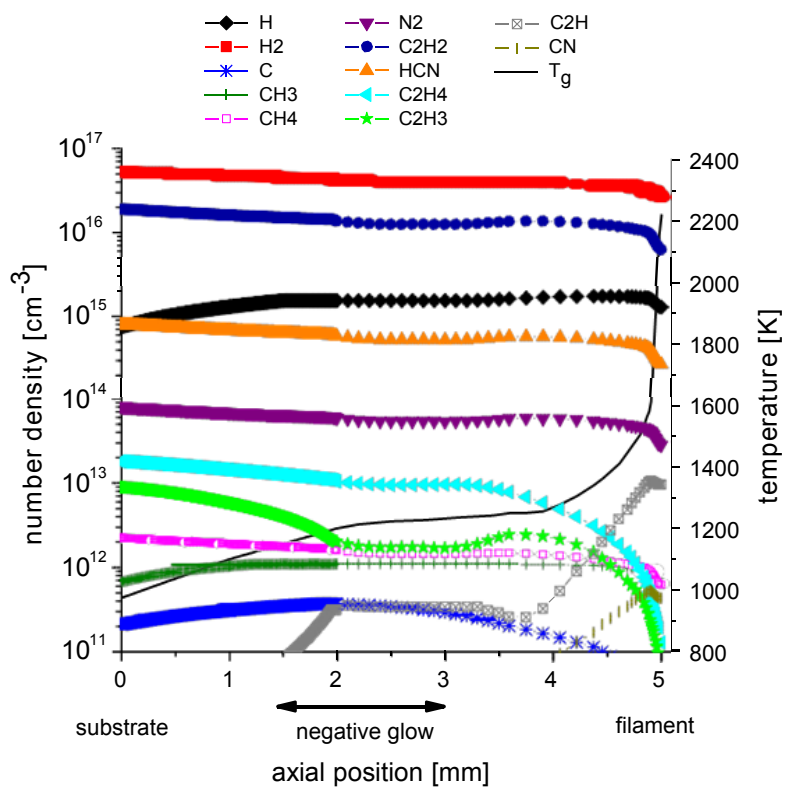

\section{Effect of the $\mathrm{NH}_{3}$ Content}

We first vary the ammonia concentration in the feed gas within 0-3\%, using PE HF CCVD mode, with all the other parameters being fixed to the "base value". Number densities of the most representative neutral and ionic species are showed in Fig. 4. Due to the small amount of added ammonia, we must not expect a significantly change in hydrogen, carbon and hydrocarbon concentrations. Indeed the influence of $1 \% \mathrm{NH}_{3}$ on density of carboncontaining species is weak, with $\mathrm{HCN}, \mathrm{CN}$ and $\mathrm{N}_{2}$ formation. With $3 \%$ of $\mathrm{NH}_{3}$, a falling off of the number densities of $\mathrm{C}$ and $\mathrm{C}_{2}$ is observed while on the other hand, HCN and CN number densities are markedly increased. For PE CCVD mode as well (not shown here), the sole effect of the addition of small amounts of $\mathrm{NH}_{3}$ also results in the production of non negligible concentrations of $\mathrm{HCN}$ and $\mathrm{CN}$ species.

Indeed, for PE CCVD and PE HF CCVD processes, adding 1\% of ammonia to the feed gas increases the number densities of HCN to $3.4910^{14}$ and $5.3910^{14} \mathrm{~cm}^{-3}$, respectively. These values corresponds to a mole fraction of $* 0.007$ and $* 0.009$ respectively. The second most abundant nitrogenated molecule is $\mathrm{N}_{2}$, with a fairly constant number density of $* 10^{14} \mathrm{~cm}^{-3}$ regardless the CCVD technique used. Smith et al. [47] have shown that due to its high dissociation energy, $\mathrm{N}_{2}$ is a chemically inactive species. By contrast, it is expected that $\mathrm{CN}$ and $\mathrm{HCN}$ molecules with a strong but more reactive bond may contribute, likewise atomic hydrogen, to enhance the chemical substrate etching, and, as heavy ions, to sputtering. These effects are illustrated by the dramatic decrease of the CNT density with ammonia content displayed by SEM in Fig. 5 and by a much better quality of the individual CNT as illustrated in TEM images of Fig. 6b for CNT obtained with 3\% ammonia. From this study, it is found that the addition of $1 \% \mathrm{NH}_{3}$ represents a good compromise to achieve a high oriented and a rather good quality CNT films as shown in Fig. 5b. The origin of the dramatic decrease of the CNT density in Fig. 5c may be explained by a poisoning of the metal catalyst. Although, it is not yet clear if either the decrease of the $\mathrm{H}$ radical concentration, or the decrease of carbon active species, or the 
Fig. 4 Comparison of plasma composition (log scale) during synthesis of carbon nanotubes without and with $1 \%$ or $3 \%$ of $\mathrm{NH}_{3}$ added to a mixture of $\mathrm{H}_{2} /$ $\mathrm{C}_{2} \mathrm{H}_{2}$ at 100 sccm (80/20): (a) PE HF CCVD mode; (b) PE CCVD mode
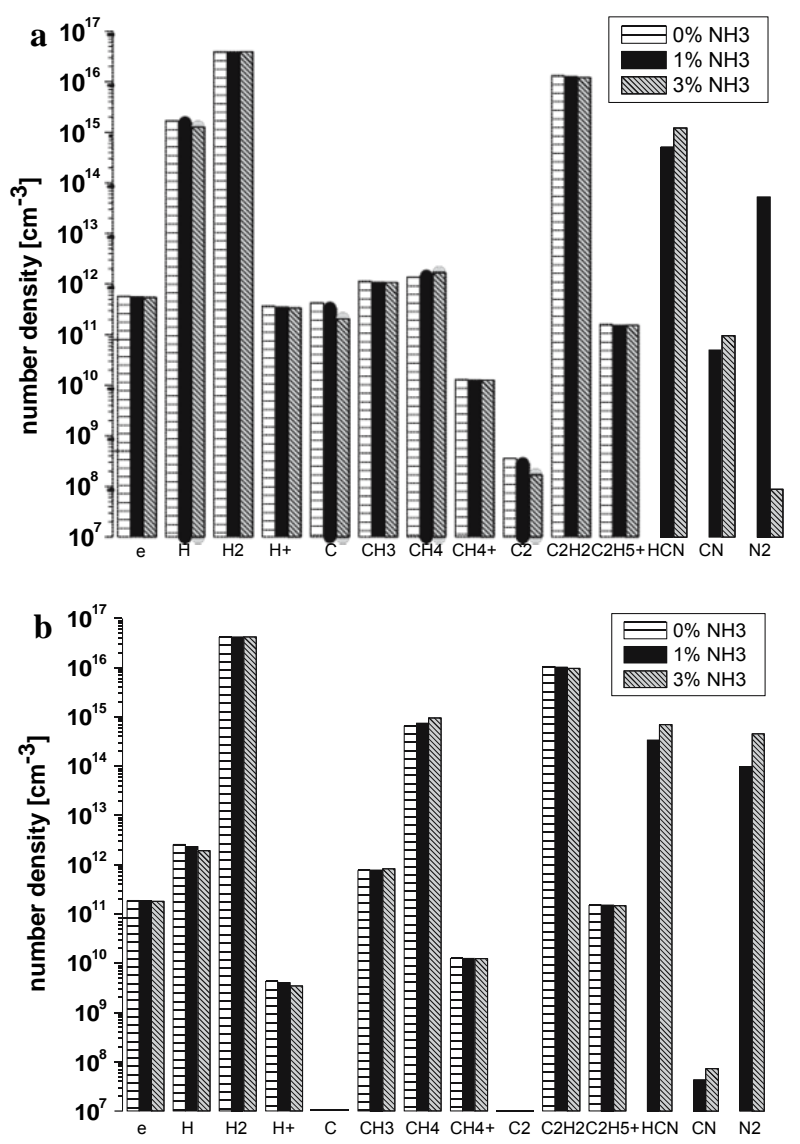

increase of $\mathrm{CN}$ and $\mathrm{HCN}$ species is the main reason of this poisoning. Probably this is a few of each of these explanations.

\section{Effect of the Gas Activation Mode}

Next, the effect of hot filaments on the gas activation is examined. Indeed, it is observed experimentally that the use of a DC CCVD mode or a DC HF CCVD mode leads to a quite different behavior in carbon deposition [19].

In filament-on mode, a CNT film without any other form of carbon deposit is obtained as shown in Fig. 7a. By contrast, in filament-off mode a film of amorphous carbon covers the whole substrate with few tiny carbon nanotubes merging from this carbon film (Fig. 7b). To discuss this strong difference, the gas phase composition was calculated using Aurora and Spin softwares in PE CCVD and PE HF CCVD conditions, respectively. Since it is believed that atomic hydrogen plays a key role in the synthesis of carbon nanotube by selective etching of amorphous carbon, we first focus our presentation and discussion of the results on the hydrogen species. We will present subsequently the carbon-containing and the charged species. Figure 8 shows the number densities of atomic and molecular 

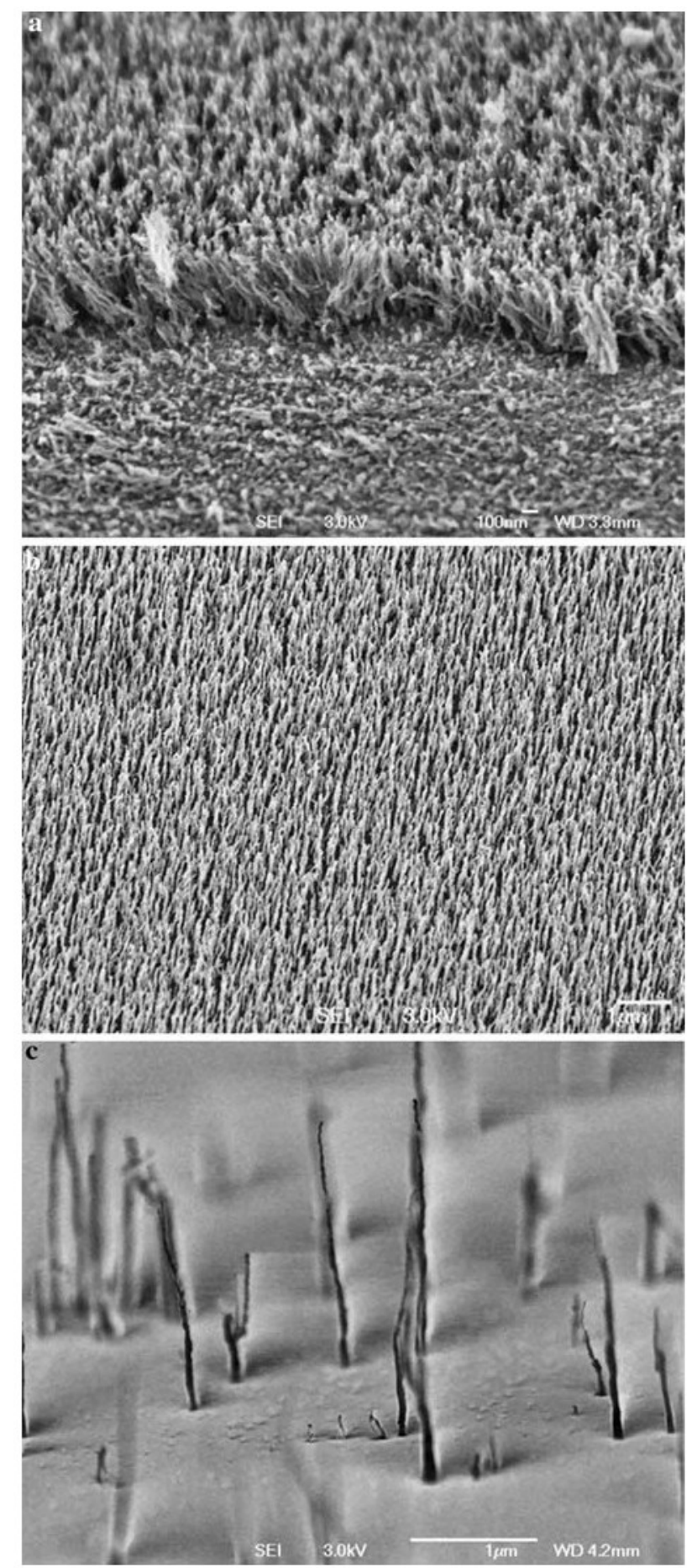

Fig. 5 SEM images of the CNT film grown with (a) $0 \%$; (b) $1 \%$ and (c) $3 \% \mathrm{NH}_{3}$. PE HF CCVD mode;

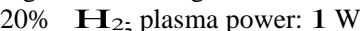




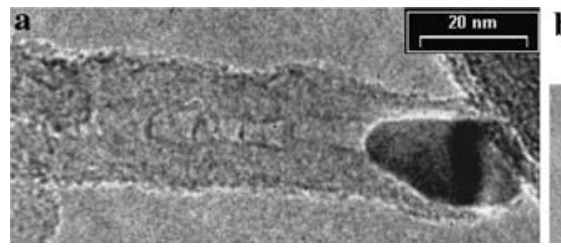

b

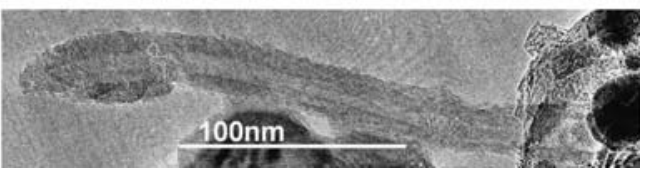

Fig. 6 TEM images of individual CNTs grown. (a) $0 \%$ and (b) $3 \% \mathrm{NH}_{3}$. PE HF CCVD mode; $20 \% \mathrm{C}_{2} \mathrm{H}_{2}$; plasma power: $1 \mathrm{~W}$
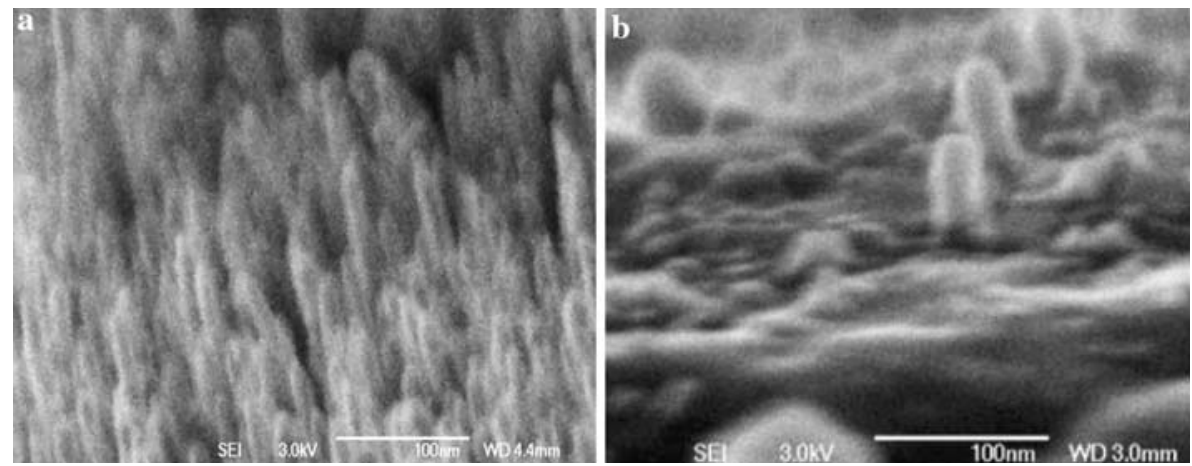

Fig. 7 Effect of the gas activation mode on the CNT growth. (a) Filament-on (DC HF CCVD) mode; (b) Filament-off (DC CCVD) mode. $\mathrm{C}_{2} \mathrm{H}_{2} / \mathrm{H}_{2}$ (20/80\%); plasma power: $1 \mathrm{~W}$

hydrogen calculated in the PE CCVD mode as a function of acetylene content in the feed gas (with $0 \%$ or $1 \%$ ammonia).

For both cases, the results indicate a weak decrease in $\mathrm{H}_{2}$ concentration with an increase in $\mathrm{C}_{2} \mathrm{H}_{2}$ gas content. This is coupled with an increase in atomic hydrogen that reach a plateau at around 25\% of $\mathrm{C}_{2} \mathrm{H}_{2}$ indicating that atomic hydrogen in PE CCVD is produced mainly by the decomposition of $\mathrm{C}_{2} \mathrm{H}_{2}$ rather than $\mathrm{H}_{2}$. Hence the concentration of $\mathrm{H}_{2}(20 \%$ $\mathrm{C}_{2} \mathrm{H}_{2}$ in gas flow) is approximately $4.2910^{16} \mathrm{~cm}^{-3}$ that represents $78.7 \%$ of mole fraction. The small decrease of molecular $\mathrm{H}_{2}$ is due to the weak $\mathrm{H}_{2}$ decomposition at $1,350 \mathrm{~K}$ and the relatively weak plasma power around $1 \mathrm{~W}$. This is in good agreement with the numerical results of Hash et al. [17] with similar conditions.

Figure 9a are presents the calculated concentrations of atomic and molecular hydrogen as a function of added acetylene in the PE HF CCVD mode. Unlike the filament-off mode shown in Fig. 8, both $\mathrm{H}$ and $\mathrm{H}_{2}$ concentrations decrease with an increasing $\mathrm{C}_{2} \mathrm{H}_{2}$ flow rate. However, since the hot filaments are very close to the negative column, the production of atomic hydrogen is now increased by about three orders of magnitude. Thus atomic hydrogen mole fraction represents *2\% in the PE HF CCVD plasma and only $50 \mathrm{ppm}$ in the PE CCVD plasma. As hydrogen radicals are strongly efficient for the etching of amorphous carbon, this huge difference can explain the growth behavior: growth of tiny CNTs and major deposition of amorphous carbon in the absence of atomic hydrogen (PE CCVD mode); growth of long CNTs in the presence of atomic hydrogen (PE HF CCVD mode). Increasing the content of $\mathrm{C}_{2} \mathrm{H}_{2}$ in the inlet mixture leads to a decrease of the concentration of atomic hydrogen in the plasma through the decrease of $\mathrm{H}_{2}$. A validation of the model is obtained by regarding the concentration of emissive species within the plasma 
Fig. 8 Calculated atomic and molecular hydrogen number densities versus $\mathrm{C}_{2} \mathrm{H}_{2}$ content in inlet gas (without or with $1 \%$ of $\mathrm{NH}_{3}$ ) during PE CCVD mode in the negative glow discharge. Plasma power $1 \mathrm{~W}$,

$\mathrm{T}_{\mathrm{g}} *(1,300-1,400) \mathrm{K}$ [The gas temperature is slightly varying from $1,300 \mathrm{~K}\left(10 \% \mathrm{C}_{2} \mathrm{H}_{2}\right)$ to $\left.1,400 \mathrm{~K}\left(30 \% \mathrm{C}_{2} \mathrm{H}_{2}\right)\right]$

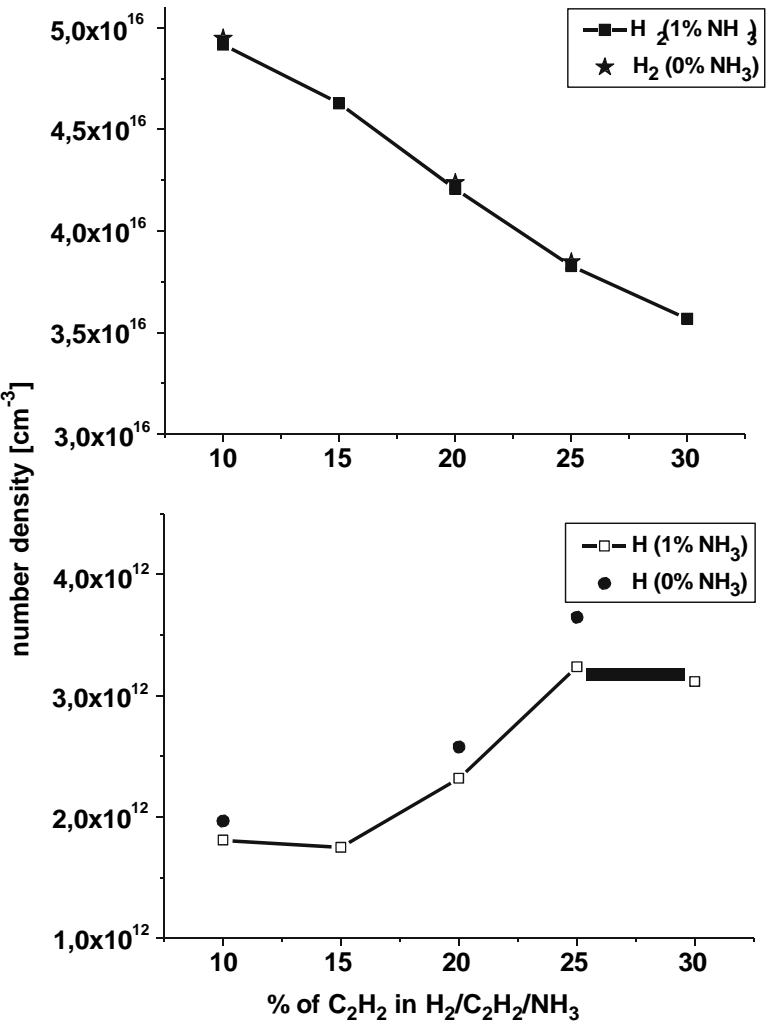

by OES during PE HF CCVD. As shown in Fig. 9, the predicted trend for atomic hydrogen is in pretty good agreement with these measurements. However, the predicted decrease of molecular hydrogen as a function of $\mathrm{C}_{2} \mathrm{H}_{2}$ content is a bit slower than the observed OES measurements.

The abundant formation of carbon monomer $\mathrm{C}$ and dimer $\mathrm{C}_{2}$ confirms the efficiency of the filament-on mode. From numerical results of Fig. 10, it can be clearly seen that the concentrations of $C$ and $C_{2}$ are respectively eight and six orders of magnitude higher in the filament-on mode. Since the formation of well-structured carbon nanotube is predominately observed during the filament-on mode, whereas amorphous carbon is the major phase during the filament-off mode, we can conclude that (i) depending on the filament activation mode, two regimes of growth exist, (ii) carbon monomers and dimers could provide carbon feedstock for nanotube growth in the filament-in mode.

As the gas-phase chemistry in the plasma is also driven by the electron kinetics, we discuss now the effect of the filament on the electron and ions composition. Figure 11 displays a comparison of the concentration of charged species in the plasma for the filament-off mode (PE CCVD) versus the filament-in mode (PE HF CCVD). Similar gas mixture with a molar composition $20 \% \mathrm{C}_{2} \mathrm{H}_{2}, 79 \% \mathrm{H}_{2}$ and $1 \% \mathrm{NH}_{3}$ is used for this study. The calculations, displayed in Fig. 11, indicate that in both cases, the most abundant positively charged ion is $\mathrm{C}_{2} \mathrm{H}_{5}^{+}$with almost identical number density. However, when the filament is activated, electron and proton $\mathrm{H}^{+}$number densities are improved by a factor of three and ten, respectively. For the electron density $\mathrm{n}_{\mathrm{e}-}$, the values calculated are 

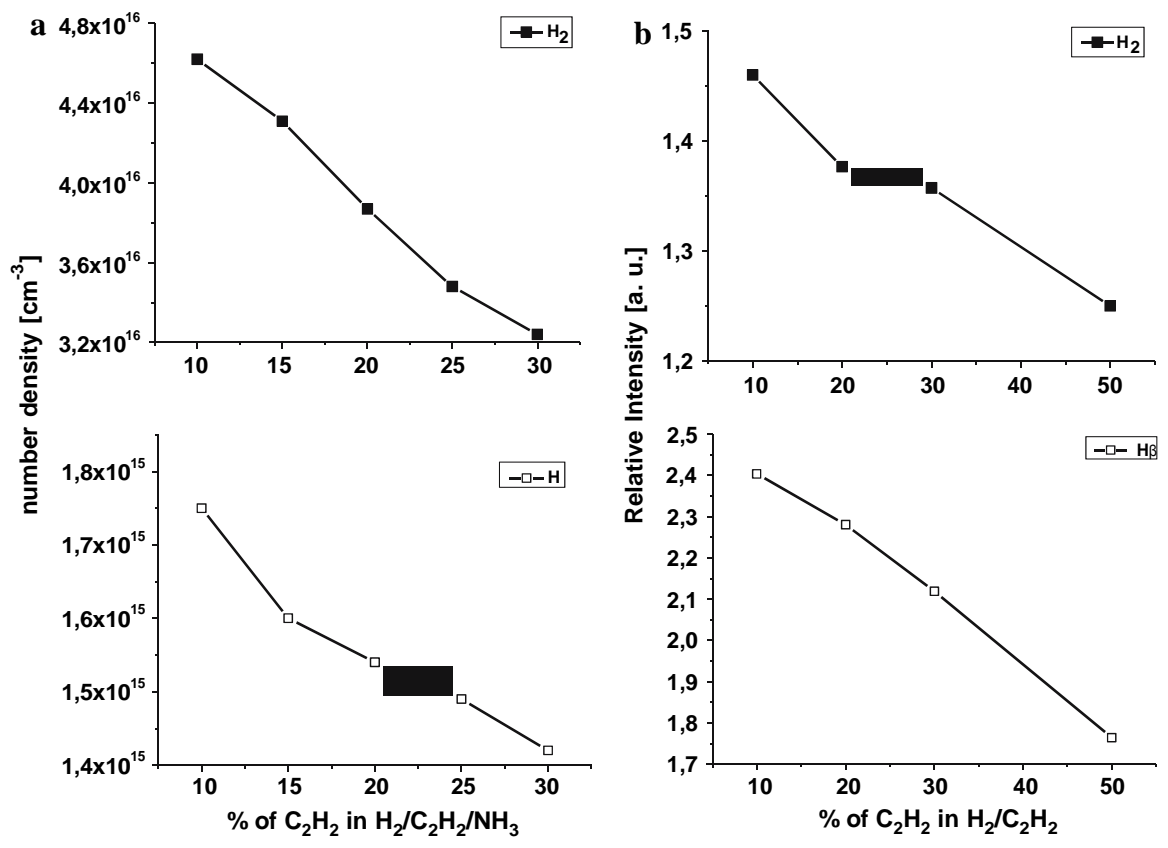

Fig. 9 Atomic and molecular hydrogen number densities versus $\mathrm{C}_{2} \mathrm{H}_{2}$ content in inlet gas (without or with $1 \%$ of $\mathrm{NH}_{3}$ ) during PE CCVD mode in the negative glow discharge. (a) Calculated with ChemKin; (b) OES relative measurements $\left(\mathrm{H}_{2}\right.$ and $\mathrm{H}_{\mathrm{b}}$ modes, respectively). $1 \% \mathrm{NH}_{3}$ in inlet mixture; plasma power $1 \mathrm{~W}$, $\mathrm{T}_{\mathrm{g}} *(1,300-1,400) \mathrm{K}, \mathrm{T}_{\mathrm{f}} * 2,200 \mathrm{~K}$

Fig. 10 Evolution of the concentrations of carbon monomer $(\mathrm{C})$ and dimer $\left(\mathrm{C}_{2}\right)$ with $\mathrm{C}_{2} \mathrm{H}_{2}$ content in PE CCVD and PE HF CCVD modes, respectively. Plasma power $1 \mathrm{~W}$ $1 \%$ of $\mathrm{NH}_{3}$ in inlet mixture, $\mathrm{T}_{\mathrm{g}} *(1,300-1,400) \mathrm{K}$, $\mathrm{T}_{\mathrm{f}} * 2,200 \mathrm{~K}$

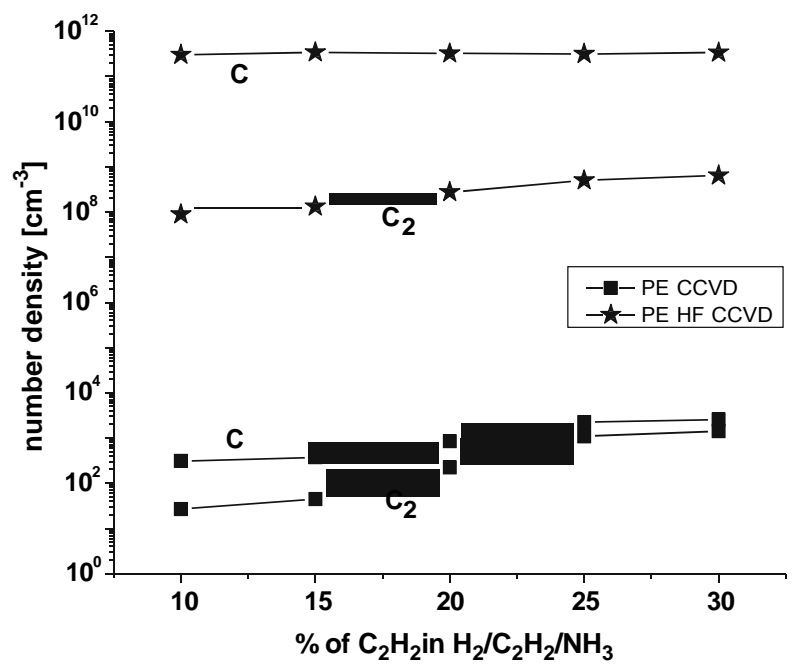

$1.8910^{11}$ and $5.6910^{11} \mathrm{~cm}^{-3}$ without and with filaments, respectively. These values correspond to a mole fraction of $3.3910^{-6}$ and $1.05910^{-5}$, respectively, in good agreement with a theoretical estimation [30] and simulations performed in similar 
Fig. 11 Calculated concentration of charged species in PE CCVD and PE HF CCVD modes. The conditions are: $20 \%$ $\mathrm{C}_{2} \mathrm{H}_{2}$ and $1 \% \mathrm{NH}_{3}$ in the inlet mixture, plasma power $1 \mathrm{~W}$, $\mathrm{T}_{\mathrm{g}} *(1,300-1,400) \mathrm{K}$, $\mathrm{T}_{\mathrm{f}} * 2,200 \mathrm{~K}$

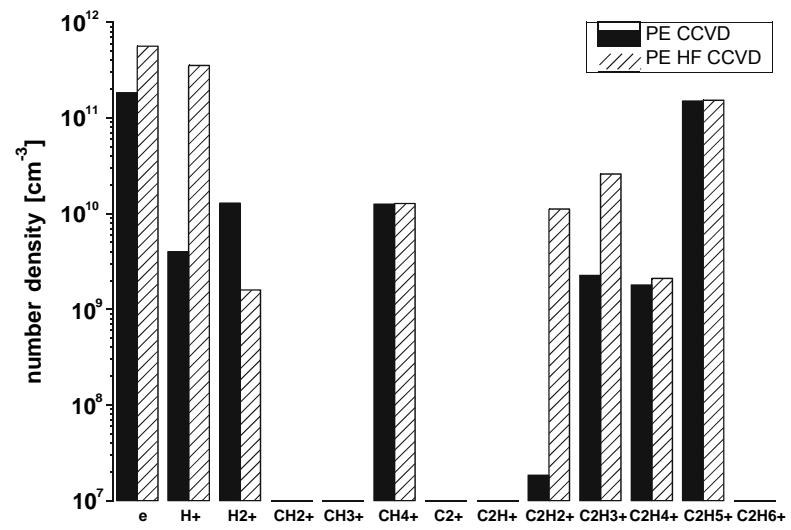

processes like microwave discharges [14, 48, 49] and DC discharges [50, 51]. Even if it must be recalled that such comparisons may be handled with care because of different experimental conditions (gas, pressure, plasma power, experimental set up, ...), nevertheless the same order of magnitude is found.

For the proton, due to the weak dissociation of $\mathrm{H}_{2}$ in PE CCVD mode, the concentration of atomic hydrogen is low, so also is the concentration of $\mathrm{H}^{+}$, despite the weaker stability of $\mathrm{H}_{2}^{+}$compared to $\mathrm{H}^{+}$(Fig. 11). However in PE HF CCVD mode, concentration of protons is by far most important due to (i) presence of radical $\mathrm{H}$ which is a few orders of magnitude higher, and (ii) decomposition of unstable $\mathrm{H}_{2}^{+}$. It is likely that the difference between concentrations of $\mathrm{H}^{+}$affects the resulted growth of carbon nanotubes. Indeed, hydrogen ions could be accelerated to the sample cathode where they participate to the sputtering of graphitic carbon and to the activation of the substrate through a competitive adsorption of hydrocarbons. It is interesting to notice that the number density of $\mathrm{H}$ radical in PE CCVD mode is only one order of magnitude higher than the one of $\mathrm{H}^{+}$in PE HF CCVD.

Finally, number densities of neutral $\mathrm{C}_{\mathrm{x}} \mathrm{H}_{\mathrm{y}}$ species with $\mathrm{x}=1,2$ and $\mathrm{y}=0 \mathrm{~B}$ y B 6 are presented in Fig. 12 for PE CCVD and PE HF CCVD processes, respectively. It can be noted for the filament-in mode : (i) a larger amount of $\mathrm{C}, \mathrm{CH}, \mathrm{CH}_{2}, \mathrm{CH}_{2}(\mathrm{~S}), \mathrm{C}_{2}$ and $\mathrm{C}_{2} \mathrm{H}$ are produced, showing thus the efficiency of the thermal dissociation at higher temperatures $* 2,000 \mathrm{~K}$; (ii) a slightly higher $\mathrm{C}_{2} \mathrm{H}_{2}$ concentration probably due to the diffusion of

Fig. 12 Comparison of the concentrations in neutral carboncontaining species in PE CCVD and PE HF CCVD modes. Same conditions as reported in Fig. 11

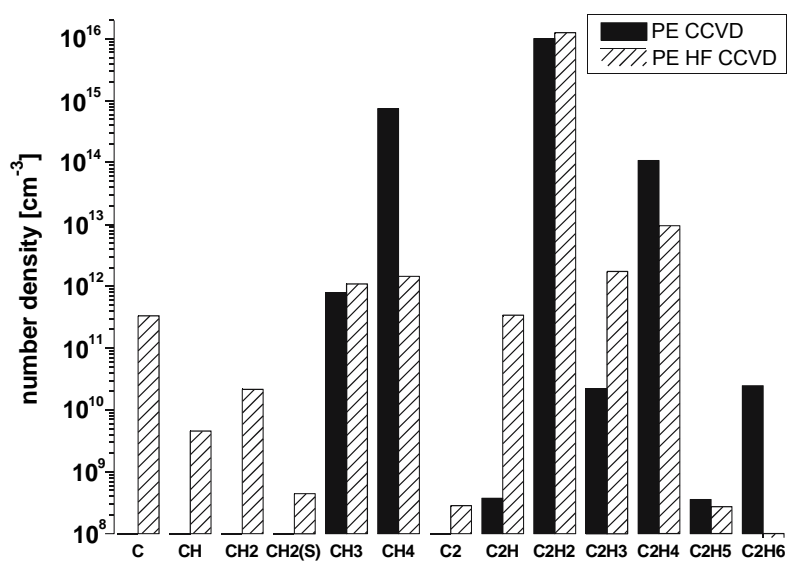


$\mathrm{C}_{2} \mathrm{H}_{2}$ from the hotter region of filaments where this molecule is more stable at high temperature. Finally we can conclude that in addition of $\mathrm{C}$ and $\mathrm{C}_{2}$ discussed above (Fig. 10), $\mathrm{CH}, \mathrm{CH}_{2}, \mathrm{CH}_{2}(\mathrm{~S}), \mathrm{CH}_{3}$ and $\mathrm{C}_{2} \mathrm{H}$ are also expected to contribute to the growth of carbon nanotubes.

\section{Effect of the $\mathrm{C}_{2} \mathrm{H}_{2}$ Partial Pressure on PE CCVD and PE HF CCVD}

It has been reported that the growth of carbon nanotubes is also dependent on the $\mathrm{C}_{2} \mathrm{H}_{2}$ partial pressure [52]. Thus we further investigate the variations of the gas activated mixture with the partial $\mathrm{C}_{2} \mathrm{H}_{2}$ pressure. In Fig. 13a the evolution of $\mathrm{C}_{2}$ number density with the molar percentage of acetylene in the inlet gas is displayed for the filament-on mode. The total pressure being constant, as a consequence the $\mathrm{C}_{2}$ number density increases with the partial pressure of acetylene, as calculated in Fig. 13a, in good agreement with the OES measurements shown in Fig. 13b. Above $25 \% \mathrm{C}_{2} \mathrm{H}_{2}$ however a net slowing down is observed. This confirms experimental observations [52] which state that $20 \%$ of acetylene is considered as the optimum gas content for carbon nanotubes synthesis. A similar behavior is also observed for calculated $\mathrm{C}_{2} \mathrm{H}$ and $\mathrm{CH}$ species, not shown here to simplify the figure. Surprisingly, when ammonia is added, there is no dependence of the concentration of carbon atoms $\mathrm{C}$ with the $\mathrm{C}_{2} \mathrm{H}_{2}$ concentration (Fig. 10). Then carbon atoms and hydrocarbons react with nitrogen and hydrogen via the reactions $\mathrm{C}+\mathrm{N}_{2}=\mathrm{CN}+\mathrm{N}$ and $\mathrm{N}+\mathrm{H}_{2}, \mathrm{HCN}+\mathrm{H}$ to produce $\mathrm{CN}$ and $\mathrm{HCN}$ species. In conclusion, the presence of ammonia in the discharge enhances the trapping of free carbon radicals and reduces their condensation as amorphous carbon. For the PE CCVD mode (Fig. 10) the same dependence was found, but yet with a much lower number density.

\section{Conclusion}

Investigation of the plasma composition in PE HF CCVD (Plasma-Enhanced Hot Filament Catalytic Chemical Vapor Deposition) of carbon nanotubes is currently underway in our

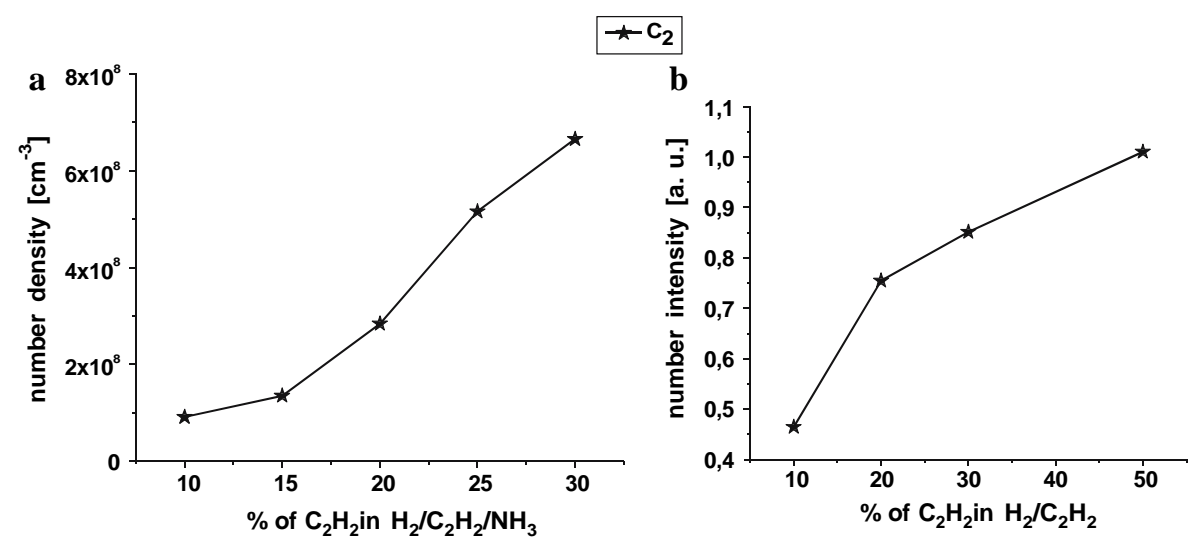

Fig. 13 Effect of the $\mathrm{C}_{2} \mathrm{H}_{2}$ partial pressure in $\mathrm{C}_{2} \mathrm{H}_{2} / \mathrm{H}_{2} / \mathrm{NH}_{3}$ mixture in PE HF CCVD mode: (a) Calculation; (b) Relative intensity extracted from OES Swan band at $516.1 \mathrm{~nm}$. $\mathrm{T}_{\mathrm{f}}=2,200 \mathrm{~K}$; other conditions identical to those reported in Fig. 8 
group. These efforts are aimed at addressing the feasibility issues of a wide range of nanotube synthesis conditions through a combination of experiments and modeling analyses. For the simulations, CHEMKIN database and software package were used with the goal to estimate the concentrations of species responsible of the formation of nanotubes. Simulations were compared with OES measurements and structural investigations were performed using SEM and TEM observations. A close comparison is undertaken with the PE CCVD mode (with filaments off). Our results indicate that the density and the morphology of the nanotubes are strongly improved when three conditions are gathered (i) an adequate percentage of ammonia, found to be $1 \%$ in our conditions (ii) an optimal acetylene percentage around $20 \%$ in the feed gas and (iii) a filament-on mode. These improvements could be explained by the crucial chemical activities of two groups of molecules (i) $\mathrm{H}, \mathrm{CN}$ and $\mathrm{HCN}$ that could help to improve the quality of nanotube through specific graphite etching (ii) $\mathrm{C}, \mathrm{C}_{2}$ but also $\mathrm{CH}_{3}, \mathrm{CH}_{2}, \mathrm{CH}_{2}(\mathrm{~S})$ and $\mathrm{C}_{2} \mathrm{H}$ that may act as growth precursors leading to two seemingly opposite growth mechanisms (carbon nanotubes or amorphous carbon) when the filament is activated or not. Thus the next step of our research will consist in the exploitation of these one-dimensional geometry results combined with a more sophisticated surface chemistry results simulating the nanotube growth. Influence of ions on the surface chemistry and their direct participation on CNTs growth will be also accounted for. We hope that such a comprehensive model will enable us to make accurate predictions about the spatial distribution of species in the reactor, as well as to calculate nanotube growth rates in different synthesis conditions. These estimations are expected to improve our understanding of the fundamental mechanisms of nanotube formation and to better control the process through controllable parameters yielding to ordered nanotube architectures and integrated devices.

Acknowledgments We are grateful to O. Crégut for assistance in OES experiment and J. Faerber for SEM images. We acknowledge also the French Ministry of Foreign Affairs for funding research fellowship for one of the authors (M.G) at IPCMS, CNRS, Strasbourg, France.

Appendices

Appendix A Arrhenius kinetic parameters for the gas-phase reactions in a $\mathrm{C}_{2} \mathrm{H}_{2} / \mathrm{H}_{2}$ mixture

\begin{tabular}{|c|c|c|c|c|c|c|}
\hline $\begin{array}{l}\text { Reaction } \\
\text { number }\end{array}$ & Reaction & $\begin{array}{l}\mathrm{A}\left(\mathrm{cm}^{3} /\right. \\
\left.\mathrm{mol}^{-1} \mathrm{~s}^{-1}\right)\end{array}$ & b & $\mathrm{E}$ [cal/mole] & Third body & Ref \\
\hline \multicolumn{7}{|c|}{ Neutral-neutral } \\
\hline 1 & $2 \mathrm{H}+\mathrm{M}, \mathrm{H}_{2}+\mathrm{M}$ & $1.00 \mathrm{E}+18$ & -1.00 & 0.0 & $\mathrm{H}_{2}, \mathrm{CH}_{4}, \mathrm{C}_{2} \mathrm{H}_{6}$ & [34] \\
\hline 2 & $2 \mathrm{H}+\mathrm{H}_{2}, 2 \mathrm{H}_{2}$ & $9.00 \mathrm{E}+16$ & -0.60 & 0.0 & & [34] \\
\hline 3 & $\mathrm{H}+\mathrm{CH}_{3}(+\mathrm{M})=\mathrm{CH}_{4}(+\mathrm{M})$ & $1.39 \mathrm{E}+16$ & -0.534 & 536.0 & $\mathrm{H}_{2}, \mathrm{CH}_{4}, \mathrm{C}_{2} \mathrm{H}_{6}$ & [34] \\
\hline 4 & $\mathrm{H}+\mathrm{CH}_{4}=\mathrm{CH}_{3}+\mathrm{H}_{2}$ & $6.60 \mathrm{E}+08$ & 1.62 & 10840.0 & & [34] \\
\hline 5 & $\mathrm{CH}+\mathrm{CH}_{4}>\mathrm{H}+\mathrm{C}_{2} \mathrm{H}_{4}$ & $6.00 \mathrm{E}+13$ & 0.00 & 0.0 & & [34] \\
\hline 6 & $\mathrm{CH}_{2}+\mathrm{CH}_{4}, 2 \mathrm{CH}_{3}$ & $2.46 \mathrm{E}+06$ & 2.00 & 8270.0 & & [34] \\
\hline 7 & $\mathrm{CH}_{2}(\mathrm{~S})+\mathrm{CH}_{4}, 2 \mathrm{CH}_{3}$ & $1.60 \mathrm{E}+13$ & 0.00 & -570.0 & & [34] \\
\hline 8 & $\mathrm{CH}_{3}+\mathrm{C}_{2} \mathrm{H}_{4}, \mathrm{C}_{2} \mathrm{H}_{3}+\mathrm{CH}_{4}$ & $2.27 \mathrm{E}+05$ & 2.00 & 9200.0 & & [34] \\
\hline 9 & $\mathrm{CH}_{3}+\mathrm{C}_{2} \mathrm{H}_{6}=\mathrm{C}_{2} \mathrm{H}_{5}+\mathrm{CH}_{4}$ & $6.14 \mathrm{E}+06$ & 1.74 & 10450.0 & & [34] \\
\hline 10 & $\mathrm{H}+\mathrm{CH}_{2}(+\mathrm{M}), \mathrm{CH}_{3}(+\mathrm{M})$ & $6.00 \mathrm{E}+14$ & 0.00 & 0.0 & $\mathrm{H}_{2}, \mathrm{CH}_{4}, \mathrm{C}_{2} \mathrm{H}_{6}$ & [34] \\
\hline
\end{tabular}


Appendix A continued

\begin{tabular}{|c|c|c|c|c|c|c|}
\hline $\begin{array}{l}\text { Reaction } \\
\text { number }\end{array}$ & Reaction & $\begin{array}{l}\mathrm{A}\left(\mathrm{cm}^{3} /\right. \\
\left.\mathrm{mol}^{-1} \mathrm{~s}^{-1}\right)\end{array}$ & b & $\mathrm{E}[\mathrm{cal} / \mathrm{mole}]$ & Third body & Ref \\
\hline 11 & $\mathrm{C}+\mathrm{CH}_{3}, \mathrm{H}+\mathrm{C}_{2} \mathrm{H}_{2}$ & $5.00 \mathrm{E}+13$ & 0.00 & 0.0 & & [34] \\
\hline 12 & $\mathrm{CH}+\mathrm{CH}_{3}, \mathrm{H}+\mathrm{C}_{2} \mathrm{H}_{3}$ & $3.00 \mathrm{E}+13$ & 0.00 & 0.0 & & [34] \\
\hline 13 & $\mathrm{CH}_{2}+\mathrm{H}_{2}=\mathrm{H}+\mathrm{CH}_{3}$ & $5.00 \mathrm{E}+05$ & 2.00 & 7230.0 & & [34] \\
\hline 14 & $\mathrm{CH}_{2}+\mathrm{CH}_{3}, \mathrm{H}+\mathrm{C}_{2} \mathrm{H}_{4}$ & $4.00 \mathrm{E}+13$ & 0.00 & 0.0 & & [34] \\
\hline 15 & $\mathrm{CH}_{2}(\mathrm{~S})+\mathrm{H}_{2}, \mathrm{CH}_{3}+\mathrm{H}$ & $7.00 \mathrm{E}+13$ & 0.00 & 0.0 & & [34] \\
\hline 16 & $\mathrm{CH}_{2}(\mathrm{~S})+\mathrm{CH}_{3}=\mathrm{H}+\mathrm{C}_{2} \mathrm{H}_{4}$ & $1.20 \mathrm{E}+13$ & 0.00 & -570.0 & & [34] \\
\hline 17 & $\mathrm{CH}_{2}(\mathrm{~S})+\mathrm{C}_{2} \mathrm{H}_{6}, \mathrm{CH}_{3}+\mathrm{C}_{2} \mathrm{H}_{5}$ & $4.00 \mathrm{E}+13$ & 0.00 & -550.0 & & [34] \\
\hline 18 & $2 \mathrm{CH}_{3}(+\mathrm{M}), \mathrm{C}_{2} \mathrm{H}_{6}(+\mathrm{M})$ & $6.77 \mathrm{E}+16$ & -1.18 & 654.0 & $\mathrm{H}_{2}, \mathrm{CH}_{4}, \mathrm{C}_{2} \mathrm{H}_{6}$ & [34] \\
\hline 19 & $2 \mathrm{CH}_{3}=\mathrm{H}+\mathrm{C}_{2} \mathrm{H}_{5}$ & $6.84 \mathrm{E}+12$ & 0.10 & 10600.0 & & [34] \\
\hline 20 & $\mathrm{CH}+\mathrm{H}_{2}(+\mathrm{M})=\mathrm{CH}_{3}(+\mathrm{M})$ & $1.97 \mathrm{E}+12$ & 0.43 & -370.0 & $\mathrm{H}_{2}, \mathrm{CH}_{4}, \mathrm{C}_{2} \mathrm{H}_{6}$ & [34] \\
\hline 21 & $\mathrm{H}+\mathrm{CH}_{2}(\mathrm{~S})=\mathrm{CH}+\mathrm{H}_{2}$ & $3.00 \mathrm{E}+13$ & 0.00 & 0.0 & & [34] \\
\hline 22 & $\mathrm{CH}_{2}(\mathrm{~S})(+\mathrm{M}), \mathrm{CH}_{2}(+\mathrm{M})$ & $1.00 \mathrm{E}+13$ & 0.00 & 0.0 & $\mathrm{H}_{2}, \mathrm{C}_{2} \mathrm{H}_{2}$ & [35] \\
\hline 23 & $\mathrm{C}+\mathrm{CH}_{2}, \mathrm{H}+\mathrm{C}_{2} \mathrm{H}$ & $5.00 \mathrm{E}+13$ & 0.00 & 0.0 & & [34] \\
\hline 24 & $\mathrm{CH}+\mathrm{H}_{2}, \mathrm{H}+\mathrm{CH}_{2}$ & $1.08 \mathrm{E}+14$ & 0.00 & 3110.0 & & [34] \\
\hline 25 & $\mathrm{CH}+\mathrm{CH}_{2}=\mathrm{H}+\mathrm{C}_{2} \mathrm{H}_{2}$ & $4.00 \mathrm{E}+13$ & 0.00 & 0.0 & & [34] \\
\hline 26 & $\mathrm{CH}_{2}+\mathrm{CH}_{2}, \mathrm{H}_{2}+\mathrm{C}_{2} \mathrm{H}_{2}$ & $1.60 \mathrm{E}+15$ & 0.00 & 11944.0 & & [34] \\
\hline 27 & $\mathrm{CH}_{2}+\mathrm{CH}_{2}>2 \mathrm{H}+\mathrm{C}_{2} \mathrm{H}_{2}$ & $2.00 \mathrm{E}+14$ & 0.00 & 10989.0 & & [34] \\
\hline 28 & $\mathrm{C}+\mathrm{CH}_{2}>2 \mathrm{CH}$ & $1.62 \mathrm{E}+12$ & 0.00 & 23550.0 & & [53] \\
\hline 29 & $\mathrm{H}+\mathrm{CH}, \mathrm{C}+\mathrm{H}_{2}$ & $1.65 \mathrm{E}+14$ & 0.00 & 0.0 & & [34] \\
\hline 30 & $C+C>C_{2}$ & $1.30 \mathrm{E}+13$ & 0.00 & 0.0 & & [54] \\
\hline 31 & $\mathrm{H}+\mathrm{C}_{2} \mathrm{H}_{5}(+\mathrm{M}), \mathrm{C}_{2} \mathrm{H}_{6}(+\mathrm{M})$ & $5.21 \mathrm{E}+17$ & -0.99 & 1580.0 & $\mathrm{H}_{2}, \mathrm{CH}_{4}, \mathrm{C}_{2} \mathrm{H}_{6}$ & [34] \\
\hline 32 & $\mathrm{H}+\mathrm{C}_{2} \mathrm{H}_{6}=\mathrm{C}_{2} \mathrm{H}_{5}+\mathrm{H}_{2}$ & $1.15 \mathrm{E}+08$ & 1.90 & 7530.0 & & [34] \\
\hline 33 & $\mathrm{H}+\mathrm{C}_{2} \mathrm{H}_{4}(+\mathrm{M}), \mathrm{C}_{2} \mathrm{H}_{5}(+\mathrm{M})$ & $0.54 \mathrm{E}+12$ & 0.454 & 1820.0 & $\mathrm{H}_{2}, \mathrm{CH}_{4}, \mathrm{C}_{2} \mathrm{H}_{6}$ & [34] \\
\hline 34 & $\mathrm{H}+\mathrm{C}_{2} \mathrm{H}_{5}=\mathrm{H}_{2}+\mathrm{C}_{2} \mathrm{H}_{4}$ & $2.00 \mathrm{E}+12$ & 0.00 & 0.0 & & [34] \\
\hline 35 & $\mathrm{H}+\mathrm{C}_{2} \mathrm{H}_{3}(+\mathrm{M})=\mathrm{C}_{2} \mathrm{H}_{4}(+\mathrm{M})$ & $6.08 \mathrm{E}+12$ & 0.27 & 280.0 & $\mathrm{H}_{2}, \mathrm{CH}_{4}, \mathrm{C}_{2} \mathrm{H}_{6}$ & [34] \\
\hline 36 & $\mathrm{H}+\mathrm{C}_{2} \mathrm{H}_{4}, \mathrm{C}_{2} \mathrm{H}_{3}+\mathrm{H}_{2}$ & $1.325 \mathrm{E}+06$ & 2.53 & 12240.0 & & [34] \\
\hline 37 & $\mathrm{C}_{2} \mathrm{H}_{4}(+\mathrm{M}), \mathrm{H}_{2}+\mathrm{C}_{2} \mathrm{H}_{2}(+\mathrm{M})$ & $8.00 \mathrm{E}+12$ & 0.44 & 86770.0 & $\mathrm{H}_{2}, \mathrm{CH}_{4}, \mathrm{C}_{2} \mathrm{H}_{6}$ & [34] \\
\hline 38 & $\mathrm{H}+\mathrm{C}_{2} \mathrm{H}_{2}(+\mathrm{M}), \mathrm{C}_{2} \mathrm{H}_{3}(+\mathrm{M})$ & $5.60 \mathrm{E}+12$ & 0.00 & 2400.0 & $\mathrm{H}_{2}, \mathrm{CH}_{4}, \mathrm{C}_{2} \mathrm{H}_{6}$ & [34] \\
\hline 39 & $\mathrm{H}+\mathrm{C}_{2} \mathrm{H}_{3}=\mathrm{H}_{2}+\mathrm{C}_{2} \mathrm{H}_{2}$ & $3.00 \mathrm{E}+13$ & 0.00 & 0.0 & & [34] \\
\hline 40 & $\mathrm{H}+\mathrm{C}_{2} \mathrm{H}(+\mathrm{M}), \mathrm{C}_{2} \mathrm{H}_{2}(+\mathrm{M})$ & $1.00 \mathrm{E}+17$ & -1.00 & 0.0 & $\mathrm{H}_{2}, \mathrm{CH}_{4}, \mathrm{C}_{2} \mathrm{H}_{6}$ & [34] \\
\hline 41 & $\mathrm{C}_{2} \mathrm{H}+\mathrm{H}_{2}>\mathrm{H}+\mathrm{C}_{2} \mathrm{H}_{2}$ & $5.68 \mathrm{E}+10$ & 0.90 & 1993.0 & & [34] \\
\hline 42 & $\mathrm{C}_{2}+\mathrm{H}_{2}, \mathrm{C}_{2} \mathrm{H}+\mathrm{H}$ & $6.60 \mathrm{E}+13$ & 0.00 & 7950.0 & & [55] \\
\hline
\end{tabular}

Appendix B Arrhenius kinetic parameters for the nitrogen-containing reactions

\begin{tabular}{lllllll}
\hline $\begin{array}{l}\text { Reaction } \\
\text { number }\end{array}$ & Reaction & $\begin{array}{l}\mathrm{A}\left(\mathrm{cm}^{3} /\right. \\
\left.\mathrm{mol}^{-1} \mathrm{~s}^{-1}\right)\end{array}$ & $\mathrm{b}$ & $\mathrm{E}$ [cal/mole] & $\begin{array}{l}\text { Third } \\
\text { body }\end{array}$ & Ref \\
\hline \multicolumn{2}{l}{ Neutral-neutral } & & & & & \\
43 & $\mathrm{NH}_{3}+\mathrm{M}, \mathrm{NH}_{2}+\mathrm{H}+\mathrm{M}$ & $2.20 \mathrm{E}+16$ & 0.00 & 93470.0 & [35] \\
44 & $\mathrm{NH}_{3}+\mathrm{H}, \mathrm{NH}_{2}+\mathrm{H}_{2}$ & $6.40 \mathrm{E}+05$ & 2.39 & 10171.0 & [35] \\
45 & $\mathrm{NH}_{2}+\mathrm{H}, \mathrm{NH}+\mathrm{H}_{2}$ & $4.00 \mathrm{E}+13$ & 0.00 & 3650.0 & [35] \\
\hline
\end{tabular}


Appendix B continued

\begin{tabular}{|c|c|c|c|c|c|c|}
\hline $\begin{array}{l}\text { Reaction } \\
\text { number }\end{array}$ & Reaction & $\begin{array}{l}\mathrm{A}\left(\mathrm{cm}^{3} /\right. \\
\left.\mathrm{mol}^{-1} \mathrm{~s}^{-1}\right)\end{array}$ & $\mathrm{b}$ & $\mathrm{E}[\mathrm{cal} / \mathrm{mole}]$ & $\begin{array}{l}\text { Third } \\
\text { body }\end{array}$ & Ref \\
\hline 46 & $\mathrm{NH}_{2}+\mathrm{NH}_{2}=\mathrm{N}_{2} \mathrm{H}_{2}+\mathrm{H}_{2}$ & $8.50 \mathrm{E}+11$ & 0.00 & 0.0 & & [35] \\
\hline 47 & $\mathrm{NH}_{2}+\mathrm{NH}_{2}=\mathrm{NH}_{3}+\mathrm{NH}$ & $5.00 \mathrm{E}+13$ & 0.00 & 10000.0 & & [35] \\
\hline 48 & $\mathrm{NH}_{2}+\mathrm{NH}_{2}(+\mathrm{M}), \mathrm{N}_{2} \mathrm{H}_{4}(+\mathrm{M})$ & $1.50 \mathrm{E}+13$ & 0.00 & 0.0 & $\mathrm{~N}_{2}, \mathrm{NH}_{3}$ & [35] \\
\hline 49 & $\mathrm{NH}_{2}+\mathrm{NH}, \mathrm{N}_{2} \mathrm{H}_{2}+\mathrm{H}$ & $5.00 \mathrm{E}+13$ & 0.00 & 0.0 & & [35] \\
\hline 50 & $\mathrm{NH}_{2}+\mathrm{N}, \mathrm{N}_{2}+2 \mathrm{H}$ & $7.00 \mathrm{E}+13$ & 0.00 & 0.0 & & [35] \\
\hline 51 & $\mathrm{NH}+\mathrm{H}, \mathrm{N}+\mathrm{H}_{2}$ & $3.00 \mathrm{E}+13$ & 0.00 & 0.0 & & [35] \\
\hline 52 & $\mathrm{NH}+\mathrm{N}, \mathrm{N}_{2}+\mathrm{H}$ & $3.00 \mathrm{E}+13$ & 0.00 & 0.0 & & [35] \\
\hline 53 & $\mathrm{NH}+\mathrm{NH}=\mathrm{N}_{2}+2 \mathrm{H}$ & $2.50 \mathrm{E}+13$ & 0.00 & 0.0 & & [35] \\
\hline 54 & $\mathrm{~N}_{2} \mathrm{H}_{4}+\mathrm{H}, \mathrm{N}_{2} \mathrm{H}_{3}+\mathrm{H}_{2}$ & $1.30 \mathrm{E}+13$ & 0.00 & 2500.0 & & [35] \\
\hline 55 & $\mathrm{~N}_{2} \mathrm{H}_{4}+\mathrm{NH}_{2}=\mathrm{N}_{2} \mathrm{H}_{3}+\mathrm{NH}_{3}$ & $3.90 \mathrm{E}+12$ & 0.00 & 1500.0 & & [35] \\
\hline 56 & $\mathrm{~N}_{2} \mathrm{H}_{3}+\mathrm{M}, \mathrm{N}_{2} \mathrm{H}_{2}+\mathrm{H}+\mathrm{M}$ & $3.50 \mathrm{E}+16$ & 0.00 & 46000.0 & & [35] \\
\hline 57 & $\mathrm{~N}_{2} \mathrm{H}_{3}+\mathrm{H}, \mathrm{NH}_{2}+\mathrm{NH}_{2}$ & $1.60 \mathrm{E}+12$ & 0.00 & 0.0 & & [35] \\
\hline 58 & $\mathrm{~N}_{2} \mathrm{H}_{3}+\mathrm{NH}=\mathrm{N}_{2} \mathrm{H}_{2}+\mathrm{NH}_{2}$ & $2.00 \mathrm{E}+13$ & 0.00 & 0.0 & & [35] \\
\hline 59 & $\mathrm{~N}_{2} \mathrm{H}_{2}+\mathrm{M}, \mathrm{NNH}+\mathrm{H}+\mathrm{M}$ & $5.00 \mathrm{E}+16$ & 0.00 & 50000.0 & $\mathrm{H}_{2}, \mathrm{~N}_{2}$ & [35] \\
\hline 60 & $\mathrm{~N}_{2} \mathrm{H}_{2}+\mathrm{H}, \mathrm{NNH}+\mathrm{H}_{2}$ & $5.00 \mathrm{E}+13$ & 0.00 & 1000.0 & & [35] \\
\hline 61 & $\mathrm{~N}_{2} \mathrm{H}_{2}+\mathrm{NH}, \mathrm{NNH}+\mathrm{NH}_{2}$ & $1.00 \mathrm{E}+13$ & 0.00 & 1000.0 & & [35] \\
\hline 62 & $\mathrm{~N}_{2} \mathrm{H}_{2}+\mathrm{NH}_{2}=\mathrm{NNH}+\mathrm{NH}_{3}$ & $1.00 \mathrm{E}+13$ & 0.00 & 1000.0 & & [35] \\
\hline 63 & $\mathrm{NNH}, \mathrm{N}_{2}+\mathrm{H}$ & $1.00 \mathrm{E}+07$ & 0.00 & 0.0 & & [35] \\
\hline 64 & $\mathrm{NNH}+\mathrm{H}, \mathrm{N}_{2}+\mathrm{H}_{2}$ & $1.00 \mathrm{E}+14$ & 0.00 & 0.0 & & [35] \\
\hline 65 & $\mathrm{NNH}+\mathrm{NH}, \mathrm{N}_{2}+\mathrm{NH}_{2}$ & $5.00 \mathrm{E}+13$ & 0.00 & 0.0 & & [35] \\
\hline 66 & $\mathrm{NNH}+\mathrm{NH} 2, \mathrm{~N}_{2}+\mathrm{NH}_{3}$ & $5.00 \mathrm{E}+13$ & 0.00 & 0.0 & & [35] \\
\hline 67 & $\mathrm{CN}+\mathrm{H}_{2}, \mathrm{HCN}+\mathrm{H}$ & $3.60 \mathrm{E}+08$ & 1.55 & 3000.0 & & [35] \\
\hline 68 & $\mathrm{HCN}+\mathrm{CN}=\mathrm{C}_{2} \mathrm{~N}_{2}+\mathrm{H}$ & $1.50 \mathrm{E}+07$ & 1.71 & 153.0 & & [35] \\
\hline 69 & $\mathrm{NCN}+\mathrm{H}, \mathrm{HCN}+\mathrm{N}$ & $1.00 \mathrm{E}+14$ & 0.00 & 0.0 & & [35] \\
\hline 70 & $\mathrm{H}_{2} \mathrm{CN}+\mathrm{M}, \mathrm{HCN}+\mathrm{H}+\mathrm{M}$ & $3.00 \mathrm{E}+14$ & 0.00 & 21857.0 & & [35] \\
\hline 71 & $\mathrm{CH}_{3}+\mathrm{N}, \mathrm{H}_{2} \mathrm{CN}+\mathrm{H}$ & $7.10 \mathrm{E}+13$ & 0.00 & 0.0 & & [35] \\
\hline 72 & $\mathrm{CH}_{2}+\mathrm{N}, \mathrm{HCN}+\mathrm{H}$ & $5.00 \mathrm{E}+13$ & 0.00 & 0.0 & & [35] \\
\hline 73 & $\mathrm{CH}_{2}+\mathrm{N}_{2}, \mathrm{HCN}+\mathrm{NH}$ & $1.00 \mathrm{E}+13$ & 0.00 & 73519.0 & & [35] \\
\hline 74 & $\mathrm{CH}+\mathrm{N}, \mathrm{CN}+\mathrm{H}$ & $1.30 \mathrm{E}+13$ & 0.00 & 0.0 & & [35] \\
\hline 75 & $\mathrm{CH}+\mathrm{N}_{2}, \mathrm{HCN}+\mathrm{N}$ & $4.40 \mathrm{E}+12$ & 0.00 & 21897.0 & & [35] \\
\hline 76 & $\mathrm{C}+\mathrm{N}_{2}=\mathrm{CN}+\mathrm{N}$ & $6.30 \mathrm{E}+13$ & 0.00 & 45999.0 & & [35] \\
\hline 77 & $\mathrm{C}_{2} \mathrm{H}_{3}+\mathrm{N}, \mathrm{HCN}+\mathrm{CH}_{2}$ & $2.00 \mathrm{E}+13$ & 0.00 & 0.0 & & [35] \\
\hline
\end{tabular}

Appendix C Arrhenius kinetic parameters for the reactions containing charged species

\begin{tabular}{|c|c|c|c|c|c|}
\hline \multicolumn{6}{|c|}{$\begin{array}{l}\text { Electron-heavy } \\
\text { particles| }\end{array}$} \\
\hline 78 & $\mathrm{e}^{-}+\mathrm{H}_{2} \Rightarrow \mathrm{H}+\mathrm{H}^{-}$ & $-2.24 \mathrm{E}+22$ & -1.45 & 9592.0 & [48] \\
\hline 79 & $\mathrm{e}^{-}+\mathrm{H}_{2} \Rightarrow \mathrm{H}_{2}^{+}+2 \mathrm{e}^{-}$ & $1.18 \mathrm{E}+16$ & 0.00 & 191481.0 & [48] \\
\hline 80 & $\mathrm{e}^{-}+\mathrm{H}_{2}^{+} \Rightarrow \mathrm{e}^{-}+\mathrm{H}^{+}+\mathrm{H}$ & $1.46 \mathrm{E}+17$ & 0.00 & 37460.0 & [48] \\
\hline
\end{tabular}


Appendix C continued

\begin{tabular}{|c|c|c|c|c|c|c|}
\hline $\begin{array}{l}\text { Reaction } \\
\text { number }\end{array}$ & Reaction & $\begin{array}{l}A\left(\mathrm{~cm}^{3} /\right. \\
\left.\mathrm{mol}^{-1} \mathrm{~s}^{-1}\right)\end{array}$ & $\beta$ & $E[\mathrm{cal} / \mathrm{mole}]$ & $\begin{array}{l}\text { Third } \\
\text { body }\end{array}$ & Ref \\
\hline 81 & $\mathrm{e}^{-}+\mathrm{H}_{2}^{+} \Rightarrow 2 \mathrm{H}$ & $9.44 \mathrm{E}+18$ & -0.60 & 0.0 & & [48] \\
\hline 82 & $\mathrm{e}^{-}+\mathrm{H}^{-} \Rightarrow 2 \mathrm{e}^{-}+\mathrm{H}$ & $1.34 \mathrm{E}+13$ & 0.90 & 22700.0 & & [48] \\
\hline 83 & $\mathrm{e}^{-}+\mathrm{H} \Rightarrow 2 \mathrm{e}^{-}+\mathrm{H}^{+}$ & $1.08 \mathrm{E}+16$ & 0.00 & 178210.0 & & [48] \\
\hline 84 & $\mathrm{e}^{-}+\mathrm{H}_{2} \Rightarrow \mathrm{e}^{-}+2 \mathrm{H}$ & $1.20 \mathrm{E}+16$ & 0.00 & 113500.0 & & [48] \\
\hline 85 & $\mathrm{e}^{-}+\mathrm{e}^{-}+\mathrm{H}^{+} \Rightarrow \mathrm{e}^{-}+\mathrm{H}$ & $3.63 \mathrm{E}+37$ & -4.00 & 0.0 & & [48] \\
\hline 86 & $\mathrm{e}^{-}+\mathrm{e}^{-}+\mathrm{H}_{2}^{+} \Rightarrow \mathrm{e}^{-}+2 \mathrm{H}$ & $3.17 \mathrm{E}+21$ & -4.50 & 0.0 & & [48] \\
\hline 87 & $\mathrm{H}^{+}+\mathrm{H}_{2} \Rightarrow \mathrm{H}+\mathrm{H}_{2}^{+}$ & $1.94 \mathrm{E}+14$ & 0.00 & 21856.0 & & [48] \\
\hline 88 & $\mathrm{H}+\mathrm{H}_{2}^{+} \Rightarrow \mathrm{H}^{+}+\mathrm{H}_{2}$ & $3.85 \mathrm{E}+14$ & 0.00 & 0.0 & & [48] \\
\hline 89 & $\mathrm{H}+\mathrm{H}^{-} \Rightarrow \mathrm{E}+2 \mathrm{H}$ & $4.50 \mathrm{E}+08$ & 1.50 & 698.0 & & [48] \\
\hline 90 & $\mathrm{H}+\mathrm{H}^{-} \Rightarrow \mathrm{E}+\mathrm{H}_{2}$ & $1.43 \mathrm{E}+15$ & -0.15 & 815.0 & & [48] \\
\hline 91 & $\mathrm{H}^{+}+\mathrm{H}^{-} \Rightarrow \mathrm{H}+\mathrm{H}$ & $1.78 \mathrm{E}+17$ & 0.00 & 1768.0 & & [48] \\
\hline 92 & $\mathrm{H}^{-}+\mathrm{H}_{2}^{+} \Rightarrow \mathrm{H}_{2}+\mathrm{H}$ & $2.08 \mathrm{E}+18$ & -0.50 & 0.0 & & [48] \\
\hline 93 & $\mathrm{e}^{-}+\mathrm{CH}_{4} \Rightarrow \mathrm{e}^{-}+\mathrm{CH}_{3}+\mathrm{H}$ & $1.24 \mathrm{E}+16$ & -0.034 & 106000.0 & & [48] \\
\hline 94 & $\mathrm{e}^{-}+\mathrm{CH}_{4} \Rightarrow \mathrm{e}^{-}+\mathrm{CH}_{2}+\mathrm{H}_{2}$ & $1.14 \mathrm{E}+16$ & -0.015 & 117000.0 & & [48] \\
\hline 95 & $\mathrm{e}^{-}+\mathrm{CH}_{4} \Rightarrow 2 \mathrm{e}^{-}+\mathrm{CH}_{4}^{+}$ & $1.82 \mathrm{E}+11$ & 1.048 & 145200.0 & & [48] \\
\hline 96 & $\mathrm{e}^{-}+\mathrm{CH}_{4} \Rightarrow 2 \mathrm{e}^{-}+\mathrm{CH}_{3}++\mathrm{H}$ & $2.72 \mathrm{E}+12$ & 0.780 & 165000.0 & & [48] \\
\hline 97 & $\mathrm{e}^{-}+\mathrm{CH}_{4} \Rightarrow 2 \mathrm{e}^{-}+\mathrm{CH}_{2}++\mathrm{H}_{2}$ & $1.04 \mathrm{E}+14$ & -0.50 & 175000.0 & & [48] \\
\hline 98 & $\mathrm{e}^{-}+\mathrm{C}_{2} \mathrm{H}_{2} \Rightarrow \mathrm{e}^{-}+\mathrm{C}_{2} \mathrm{H}+\mathrm{H}$ & $4.07 \mathrm{E}+14$ & -0.50 & 116000.0 & & [48] \\
\hline 99 & $\mathrm{e}^{-}+\mathrm{C}_{2} \mathrm{H}_{2} \Rightarrow 2 \mathrm{e}^{-}+\mathrm{C}_{2} \mathrm{H}_{2}^{+}$ & $3.71 \mathrm{E}+14$ & -0.50 & 116000.0 & & [48] \\
\hline 100 & $\mathrm{e}^{-}+\mathrm{C}_{2} \mathrm{H}_{4} \Rightarrow 2 \mathrm{e}^{-}+\mathrm{C}_{2} \mathrm{H}_{4}^{+}$ & $4.33 \mathrm{E}+14$ & -0.50 & 119000.0 & & [48] \\
\hline 101 & $\mathrm{e}^{-}+\mathrm{C}_{2} \mathrm{H}_{4} \Rightarrow \mathrm{e}^{-}+\mathrm{C}_{2} \mathrm{H}_{2}+\mathrm{H}_{2}$ & $4.80 \mathrm{E}+14$ & -0.50 & 116000.0 & & [48] \\
\hline 102 & $\mathrm{e}^{-}+\mathrm{C}_{2} \mathrm{H}_{6} \Rightarrow \mathrm{e}^{-}+\mathrm{C}_{2} \mathrm{H}_{4}+\mathrm{H}_{2}$ & $4.94 \mathrm{E}+14$ & -0.50 & 118000.0 & & [48] \\
\hline 103 & $\mathrm{e}^{-}+\mathrm{C}_{2} \mathrm{H}_{6} \Rightarrow 2 \mathrm{e}^{-}+\mathrm{C}_{2} \mathrm{H}_{6}^{+}$ & $1.69 \mathrm{E}+14$ & -0.50 & 132000.0 & & [48] \\
\hline 104 & $\mathrm{e}^{-}+\mathrm{C}_{2} \mathrm{H}_{6} \Rightarrow 2 \mathrm{e}^{-}+\mathrm{C}_{2} \mathrm{H}_{5}^{+}+\mathrm{H}$ & $1.57 \mathrm{E}+14$ & -0.50 & 140000.0 & & [48] \\
\hline 105 & $\mathrm{e}^{-}+\mathrm{C}_{2} \mathrm{H}_{6} \Rightarrow 2 \mathrm{e}^{-}+\mathrm{C}_{2} \mathrm{H}_{4}^{+}+\mathrm{H}_{2}$ & $3.37 \mathrm{E}+14$ & -0.50 & 140000.0 & & [48] \\
\hline \multicolumn{7}{|c|}{ Ion-neutral } \\
\hline 106 & $\mathrm{H}^{-}+\mathrm{CH}_{4}^{+} \Rightarrow \mathrm{CH}_{4}+\mathrm{H}$ & $2.00 \mathrm{E}+18$ & -0.50 & 0.0 & & [48] \\
\hline 107 & $\mathrm{H}^{-}+\mathrm{CH}_{3}^{+} \Rightarrow \mathrm{CH}_{4}$ & $2.00 \mathrm{E}+18$ & -0.50 & 0.0 & & [48] \\
\hline 108 & $\mathrm{H}^{-}+\mathrm{CH}_{2}^{+} \Rightarrow \mathrm{CH}_{3}$ & $2.00 \mathrm{E}+18$ & -0.50 & 0.0 & & [48] \\
\hline 109 & $\mathrm{H}^{-}+\mathrm{C}_{2} \mathrm{H}_{6}^{+} \Rightarrow \mathrm{C}_{2} \mathrm{H}_{6}+\mathrm{H}$ & $2.00 \mathrm{E}+18$ & -0.50 & 0.0 & & [48] \\
\hline 110 & $\mathrm{H}^{-}+\mathrm{C}_{2} \mathrm{H}_{5}^{+} \Rightarrow \mathrm{C}_{2} \mathrm{H}_{6}$ & $2.00 \mathrm{E}+18$ & -0.50 & 0.0 & & [48] \\
\hline 111 & $\mathrm{H}^{-}+\mathrm{C}_{2} \mathrm{H}_{4}^{+} \Rightarrow \mathrm{C}_{2} \mathrm{H}_{5}$ & $2.00 \mathrm{E}+18$ & -0.50 & 0.0 & & [48] \\
\hline 112 & $\mathrm{H}^{-}+\mathrm{C}_{2} \mathrm{H}_{3}^{+} \Rightarrow \mathrm{C}_{2} \mathrm{H}_{4}$ & $2.00 \mathrm{E}+18$ & -0.50 & 0.0 & & [48] \\
\hline 113 & $\mathrm{H}^{-}+\mathrm{C}_{2} \mathrm{H}_{2}^{+} \Rightarrow \mathrm{C}_{2} \mathrm{H}_{2}+\mathrm{H}$ & $2.00 \mathrm{E}+18$ & -0.50 & 0.0 & & [48] \\
\hline 114 & $\mathrm{CH}_{3}^{+}+\mathrm{CH}_{4} \Rightarrow \mathrm{C}_{2} \mathrm{H}_{5}^{+}+\mathrm{H}_{2}$ & $4.17 \mathrm{E}+13$ & 0.50 & 0.0 & & [48] \\
\hline 115 & $\mathrm{CH}_{3}^{+}+\mathrm{CH}_{4} \Rightarrow \mathrm{CH}_{4}^{+}+\mathrm{CH}_{3}$ & $4.73 \mathrm{E}+12$ & 0.50 & 0.0 & & [48] \\
\hline 116 & $\mathrm{CH}_{2}^{+}+\mathrm{H}_{2} \Rightarrow \mathrm{CH}_{3}^{+}+\mathrm{H}$ & $5.56 \mathrm{E}+13$ & 0.50 & 0.0 & & [48] \\
\hline 117 & $\mathrm{CH}_{2}^{+}+\mathrm{CH}_{4} \Rightarrow \mathrm{C}_{2} \mathrm{H}_{5}^{+}+\mathrm{H}$ & $1.25 \mathrm{E}+13$ & 0.50 & 0.0 & & [48] \\
\hline 118 & $\mathrm{CH}_{2}^{+}+\mathrm{CH}_{4} \Rightarrow \mathrm{C}_{2} \mathrm{H}_{3}^{+}+\mathrm{H}_{2}+\mathrm{H}$ & $8.03 \mathrm{E}+12$ & 0.50 & 0.0 & & [48] \\
\hline 119 & $\mathrm{CH}_{2}^{+}+\mathrm{CH}_{4} \Rightarrow \mathrm{C}_{2} \mathrm{H}_{2}^{+}+2 \mathrm{H}_{2}$ & $1.38 \mathrm{E}+13$ & 0.50 & 0.0 & & [48] \\
\hline 120 & $\mathrm{CH}_{2}^{+}+\mathrm{CH}_{4} \Rightarrow \mathrm{CH}_{3}^{+}+\mathrm{CH}_{3}$ & $4.80 \mathrm{E}+12$ & 0.50 & 0.0 & & [48] \\
\hline 121 & $\mathrm{C}_{2} \mathrm{H}_{2}^{+}+\mathrm{CH}_{4} \Rightarrow \mathrm{C}_{2} \mathrm{H}_{3}^{+}+\mathrm{CH}_{3}$ & $1.43 \mathrm{E}+14$ & 0.50 & 0.0 & & [48] \\
\hline 122 & $\mathrm{C}_{2} \mathrm{H}_{3}^{+}+\mathrm{C}_{2} \mathrm{H}_{4} \Rightarrow \mathrm{C}_{2} \mathrm{H}_{5}^{+}+\mathrm{C}_{2} \mathrm{H}_{2}$ & $7.99 \mathrm{E}+12$ & 0.50 & 0.0 & & [48] \\
\hline
\end{tabular}


Appendix D Surface reaction mechanism for catalytic growth of tubular structures (NT) from transition metal free (Co) and filled (T) cobalt sites, described by Arrhenius equation

\begin{tabular}{|c|c|c|c|c|c|}
\hline $\begin{array}{l}\text { Reaction } \\
\text { number }\end{array}$ & Reaction & $A\left(\mathrm{~cm}^{3} / \mathrm{mol}^{-1} \mathrm{~s}^{-1}\right)$ & $\beta$ & $E[\mathrm{cal} / \mathrm{mole}]$ & Ref \\
\hline 1 & $\mathrm{Co}(\mathrm{S})+\mathrm{H} \Leftrightarrow \mathrm{TH}(\mathrm{S})$ & $1.0 \mathrm{E}+13$ & 0.0 & 0.0 & [40] \\
\hline 2 & $\mathrm{TH}(\mathrm{S})+\mathrm{H} \Leftrightarrow \mathrm{Co}(\mathrm{S})+\mathrm{H}_{2}$ & $1.3 \mathrm{E}+14$ & 0.0 & 7.3 & [40] \\
\hline 3 & $\mathrm{Co}(\mathrm{S})+\mathrm{C} \Leftrightarrow \mathrm{TC}(\mathrm{S})$ & $5.0 \mathrm{E}+12$ & 0.0 & 0.0 & \\
\hline 4 & $\mathrm{Co}(\mathrm{S})+\mathrm{CH} \Leftrightarrow \mathrm{TCH}(\mathrm{S})$ & $5.0 \mathrm{E}+12$ & 0.0 & 0.0 & \\
\hline 5 & $\mathrm{Co}(\mathrm{S})+\mathrm{CH}_{2} \Leftrightarrow \mathrm{TCH}_{2}(\mathrm{~S})$ & $5.0 \mathrm{E}+12$ & 0.0 & 0.0 & \\
\hline 6 & $\mathrm{Co}(\mathrm{S})+\mathrm{CH}_{3} \Leftrightarrow \mathrm{TCH}_{3}(\mathrm{~S})$ & $5.0 \mathrm{E}+12$ & 0.0 & 0.0 & [40] \\
\hline 7 & $\mathrm{Co}(\mathrm{S})+\mathrm{C}_{2} \Leftrightarrow \mathrm{TC}_{2}(\mathrm{~S})$ & $8.0 \mathrm{E}+10$ & 0.0 & 7.7 & \\
\hline 8 & $\mathrm{Co}(\mathrm{S})+\mathrm{C}_{2} \mathrm{H} \Leftrightarrow \mathrm{TC}_{2} \mathrm{H}(\mathrm{S})$ & $8.0 \mathrm{E}+10$ & 0.0 & 7.7 & \\
\hline 9 & $\mathrm{Co}(\mathrm{S})+\mathrm{C}_{2} \mathrm{H}_{2} \Leftrightarrow \mathrm{TC}_{2} \mathrm{H}_{2}(\mathrm{~S})$ & $8.0 \mathrm{E}+10$ & 0.0 & 7.7 & {$[40]$} \\
\hline 10 & $\mathrm{Co}(\mathrm{S})+\mathrm{C}_{2} \mathrm{H}_{3} \Leftrightarrow \mathrm{TC}_{2} \mathrm{H}_{3}(\mathrm{~S})$ & $8.0 \mathrm{E}+10$ & 0.0 & 7.7 & \\
\hline 11 & $\mathrm{Co}(\mathrm{S})+\mathrm{C}_{2} \mathrm{H}_{4} \Leftrightarrow \mathrm{TC}_{2} \mathrm{H}_{4}(\mathrm{~S})$ & $8.0 \mathrm{E}+10$ & 0.0 & 7.7 & \\
\hline 12 & $\mathrm{Co}(\mathrm{S})+\mathrm{C}_{2} \mathrm{H}_{5} \Leftrightarrow \mathrm{TC}_{2} \mathrm{H}_{5}(\mathrm{~S})$ & $8.0 \mathrm{E}+10$ & 0.0 & 7.7 & \\
\hline 13 & $\mathrm{TCH}_{3}(\mathrm{~S})+\mathrm{H} \Leftrightarrow \mathrm{TCH}_{2}(\mathrm{~S})+\mathrm{H}_{2}$ & $2.8 \mathrm{E}+07$ & 2.0 & 7,700 & [40] \\
\hline 14 & $\mathrm{TCH}_{2}(\mathrm{~S})+\mathrm{H} \Leftrightarrow \mathrm{TCH}_{3}(\mathrm{~S})$ & $1.0 \mathrm{E}+13$ & 0.0 & 0.0 & [40] \\
\hline 15 & $\mathrm{TCH}_{2}(\mathrm{~S})+\mathrm{H} \Leftrightarrow \mathrm{TCH}(\mathrm{S})+\mathrm{H}_{2}$ & $2.8 \mathrm{E}+07$ & 2.0 & 7,700 & [40] \\
\hline 16 & $\mathrm{TCH}(\mathrm{S})+\mathrm{H} \Leftrightarrow \mathrm{TCH}_{2}(\mathrm{~S})$ & $1.0 \mathrm{E}+13$ & 0.0 & 0.0 & [40] \\
\hline 17 & $\mathrm{TCH}_{2}(\mathrm{~S})+\mathrm{H} \Leftrightarrow \mathrm{Co}(\mathrm{S})+\mathrm{CH}_{3}$ & $3.0 \mathrm{E}+13$ & 0.0 & 0.0 & [40] \\
\hline 18 & $\mathrm{TCH}(\mathrm{S})+\mathrm{H} \Leftrightarrow \mathrm{TC}(\mathrm{S})+\mathrm{H}_{2}$ & $2.8 \mathrm{E}+07$ & 2.0 & 7,700 & [40] \\
\hline 19 & $\mathrm{TC}(\mathrm{S})+\mathrm{H} \Leftrightarrow \mathrm{TCH}(\mathrm{S})$ & $1.0 \mathrm{E}+13$ & 0.0 & 0.0 & [40] \\
\hline 20 & $\mathrm{TCH}(\mathrm{S})+\mathrm{CH}_{3} \Leftrightarrow \mathrm{TC}_{2} \mathrm{H}_{4}(\mathrm{~S})$ & $5.0 \mathrm{E}+12$ & 0.0 & 0.0 & [40] \\
\hline 21 & $\mathrm{TCH}_{2}(\mathrm{~S})+\mathrm{CH}_{3} \Leftrightarrow \mathrm{TC}_{2} \mathrm{H}_{5}(\mathrm{~S})$ & $5.0 \mathrm{E}+12$ & 0.0 & 0.0 & [40] \\
\hline 22 & $\mathrm{TC}_{2} \mathrm{H}_{5}(\mathrm{~S})+\mathrm{H} \Leftrightarrow \mathrm{TC}_{2} \mathrm{H}_{4}(\mathrm{~S})+\mathrm{H}_{2}$ & $9.0 \mathrm{E}+06$ & 2.0 & 5,000 & [40] \\
\hline 23 & $\mathrm{TC}_{2} \mathrm{H}_{4}(\mathrm{~S})+\mathrm{H} \Leftrightarrow \mathrm{TC}_{2} \mathrm{H}_{5}(\mathrm{~S})$ & $2.0 \mathrm{E}+13$ & 0.0 & 0.0 & [40] \\
\hline 24 & $\mathrm{TC}_{2} \mathrm{H}_{4}(\mathrm{~S})+\mathrm{H} \Leftrightarrow \mathrm{TC}_{2} \mathrm{H}_{3}(\mathrm{~S})+\mathrm{H}_{2}$ & $9.0 \mathrm{E}+06$ & 2.0 & 5,000 & [40] \\
\hline 25 & $\mathrm{TC}_{2} \mathrm{H}_{3}(\mathrm{~S})+\mathrm{H} \Leftrightarrow \mathrm{TC}_{2} \mathrm{H}_{4}(\mathrm{~S})$ & $2.0 \mathrm{E}+13$ & 0.0 & 0.0 & [40] \\
\hline 26 & $\mathrm{TC}_{2} \mathrm{H}(\mathrm{S})+\mathrm{H} \Leftrightarrow \mathrm{TC}_{2}(\mathrm{~S})+\mathrm{H}_{2}$ & $4.0 \mathrm{E}+08$ & 2.0 & 5,000 & \\
\hline 27 & $\mathrm{TC}_{2} \mathrm{H}_{2}(\mathrm{~S})+\mathrm{H} \Leftrightarrow \mathrm{TC}_{2} \mathrm{H}(\mathrm{S})+\mathrm{H}_{2}$ & $4.0 \mathrm{E}+08$ & 2.0 & 5,000 & \\
\hline 28 & $\mathrm{TC}(\mathrm{S}) \Rightarrow \mathrm{Co}(\mathrm{S})+\mathrm{NT}$ & $5.0 \mathrm{E}+15$ & 0.0 & 0.0 & \\
\hline 29 & $\mathrm{TCH}(\mathrm{S}) \Rightarrow \mathrm{Co}(\mathrm{S})+\mathrm{NT}+\mathrm{H}$ & $5.0 \mathrm{E}+15$ & 0.0 & 0.0 & \\
\hline 30 & $\mathrm{TCH}_{2}(\mathrm{~S}) \Rightarrow \mathrm{Co}(\mathrm{S})+\mathrm{NT}+2 \mathrm{H}$ & $5.0 \mathrm{E}+15$ & 0.0 & 0.0 & \\
\hline 31 & $\mathrm{TCH}_{3}(\mathrm{~S}) \Rightarrow \mathrm{Co}(\mathrm{S})+\mathrm{NT}+3 \mathrm{H}$ & $5.0 \mathrm{E}+15$ & 0.0 & 0.0 & \\
\hline 32 & $\mathrm{TC}_{2}(\mathrm{~S}) \Rightarrow \mathrm{Co}(\mathrm{S})+2 \mathrm{NT}$ & $5.0 \mathrm{E}+15$ & 0.0 & 0.0 & \\
\hline 33 & $\mathrm{TC}_{2} \mathrm{H}(\mathrm{S}) \Rightarrow \mathrm{Co}(\mathrm{S})+2 \mathrm{NT}+\mathrm{H}$ & $5.0 \mathrm{E}+15$ & 0.0 & 0.0 & \\
\hline
\end{tabular}

\section{References}

1. Loiseau A, Gadelle P, Peigney P, Blasé X, Charlier JC, Ducastelle M (2006) In Understanding carbon nanotubes: from theory to applications, chap 2. Springer, Berlin, p 49

2. Borisenko DN, Kolesnikov NN, Kulakov MP, Kveder VV (2002) Int J Nanosci 1:235

3. Dresselhaus MS, Dresselhaus G, Avouris P (2001) in Carbon nanotubes: synthesis, structure, properties and applications, Springer, Berlin, p 29 
4. Melechko AV, Merkulov VI, MacKnight TE, Guillorn MA, Klein KL, Lowndes DH, Simpson ML (2005) J Appl Phys 97:041301

5. Baker RTK (1989) Carbon 27:315

6. Cojocaru CS, Senger A, Le Normand F (2006) J of Nanosci Nanotechnol 6:1

7. Liu K, Jiang KL, Feng C, Chen Z, Fan SS (2005) Carbon 43:2850

8. Ni L, Kuroda K, Zhou LP, Kizuka T, Ohta K, Matsuishi K, Nakamura J (2006) Carbon 44:2265

9. Svrcek V, Dintzer T, Paillaud JL, Kleps I, Cracioniou F, Pham-Huu C, Ledoux MJ, Le Normand F (2006) J Chem Physics 124:184705

10. Frenklach M, Wang H (1991) Phys Rev B 43:2

11. Coltrin ME, Dandy DS (1993) J Appl Phys 74:9

12. Mankelevich YA, Rakhimov AT, Suetin NV (1998) Diam Rel Mater 7:1133

13. Gicquel A, Hassouni K, Farhat S, Breton Y, Scott CD, Lefebvre M, Pealat M (1994) Diam Rel Mater 3:581

14. Lombardi G, Hassouni K, Stancu GD, Mechold L, Ropcke J, Gicquel A (2005) J Appl Phys 98:053303

15. Hinkov I, Farhat S, Scott CD (2005) Carbon 43:2453

16. Hash D, Bose D, Govindan TR, Meyyappan M (2003) J Appl Phys 93:10

17. Hash DB, Bell MS, Teo KBK, Cruden BA, Milne WI, Meyyappan M (2005) Nanotechnology 16:925

18. Ren ZF, Huang ZP, Xu JW, Wang JH, Bush P, Siegal MP, Provencio PN (1998) Science 282:1105

19. Cojocaru CS, Le Normand F (2006) Thin Solid Films 515:53

20. Cojocaru CS, Larijani M, Misra DS, Singh MK, Veis P, Le Normand F (2004) Diam Rel Mater 13:270

21. Larijani MM, Cojocaru CS, Crégut O, Le Normand F (2007) Appl Surf Sci 253:4051

22. Herzberg G (1950) Molecular spectra and molecular structure, vol 1, 2nd edn. Van Nostrand Reinhold Company, New York

23. Pearse RWB, Gaydon AG (1984) The identification of molecular spectra. Chapman and Hill, New York

24. Veis P, Cojocaru CS, Le Normand F (2004) Acta Physica Universitatis Comenianae, XLIV-XLV, 95

25. Kee RJ, Rupley FM, Miller JA et al (2005) CHEMKIN Release 4.0.2, Reaction Design. San Diego, CA

26. Smith JA, Cameron E, Ashfold MNR, Mankelevitch YA, Suetin NV (2001) Diam Rel Mater 10:358

27. Hickmott TW (1960) J Chem Phys 32:810

28. Zheng W, Gallagher A (2006) Thin Solid Films 501:21

29. Udelson BJ, Creedon JE, French JC (1957) J Appl Phys 28:6

30. Massines F, Rabehi A, Decomps P, Ben Gadri R, Ségur P, Mayoux C (1998) J Appl Phys 83:6

31. Palmero A, van Hattum ED, Arnoldbik WM, Habraken FHPM (2004) Surf Coat Tech 188-189:392

32. Gu L, Lieberman MA (1998) J Vac Sci Technol A 6:2960

33. McGinnis SP, Kelly MA, Hagstrom SB (1995) Appl Phys Lett 66:3117

34. Smith GP, David Golden M et al, GRI-Mech 3.0, http://www.me.berkeley.edu/gri_mech/.Accessed 22 May 2006

35. Coda Zabetta E, Hupa M (2006) A detailed kinetic mechanism with methanol for simulating biomass combustion and N-pollutants, submitted to international scientific journal, http://web.abo.fi/fak/ktf/cmc/ research/index.html. Accessed 11 May 2006

36. Burcat A, Ideal gas thermodynamic data in polynomial form for combustion and air pollution use, http://www.garfield.chem.elte.hu/Burcat/burcat.html. Accessed 18 July 2006

37. Bhimarasetti G, Sunkara MK (2003) Thin Solid Films 440:78

38. Marinov NM, Pitz WJ, Westbrook CK, Vincitore AM, Castaldi MJ, Senkan SM (1998) Combust Flame $114: 192$

39. Howard JB et al, MIT combustion research, http://www.web.mit.edu/anish/www/MITcomb.html. Accessed 18 July 2006

40. Grujicic M, Cao G, Gersten B (2002) Appl Surf Sci 191:223

41. Grujicic M, Cao G, Gersten B (2002) Mater Sci Eng B 94:247

42. Hofmann S, Cantoro M, Kleinsorge B, Casiraghi C, Parvez A, Robertson J, Ducati G (2005) J Appl Phys 98:034308

43. Gohier A, Minea TM, Djouadi MA, Granier A (2007) J Appl Phys 101:054317

44. Srivastava SK, Vankar VD, Kumar V (2006) Thin Solid Films 515:1552

45. Wang EG, Guo ZG, Ma J, Zhou MM, Pu YK, Liu S, Zhang GY, Zhong DY (2003) Carbon 41:1827

46. Bratescu MA, Suda Y, Sakai Y, Saito N, Takai O (2006) Thin Solid Films 515:1314

47. Smith JA, Wills JB, Moores HS, Orr-Ewing AJ, Mankelevitch YA, Ashfold MNR, Suetin NV (2002) J Appl Phys 92:672

48. Farhat S, Silva F, Hassouni K, Gicquel A (1997) Joint International Meeting of the Electrochemical Society, Paris, 1.9-5.9

49. Hassouni K, Lombardi G, Duten X, Haagelar G, Silva F, Gicquel A, Grotjohn TA, Capitelli M, Ropcke J (2006) Plasma Sources Sci Technol 15:117 
50. Kutasi K, Hartmann P, Bánó G, Donkó Z (2005) Plasma Sources Sci Technol 14:S1

51. Muraoka K, Uchino K, Yamagata Y, Noguchi Y, Mansour M, Suanpoot P, Narishige S, Noguchi M (2002) Plasma Sources Sci Technol 11:A143

52. Bell MS, Lacerda RG, Teo KBK, Rupesinghe NL, Amaratunga GAJ, Milne WI, Chhowalla M (2004) Appl Phys Lett 85:7

53. Woodall J, Agúndez M, Markwick-Kemper AJ, Millar TJ, udfa 05-The UMIST database for Astrochemistry, http://www.udfa.net/. Accessed 13 May 2006

54. NIST Chemical Kinetics Database on the Web, Standard Reference Database 17, Version 7.0, Release 1.4, http://www.kinetics.nist.gov/kinetics/index.jsp. Accessed 22 June 2006

55. Konnov AA (1998) Detailed reaction mechanism for small hydrocarbons combustion. Release 0.4 http://www.homepages.vub.ac.be/*akonnov/. Accessed 27 May 2006 